"This is the peer reviewed version of the following article: [Chem.-Eur. 2015, 21,15188-15200], which has been published in final form at [Link to final article using the DOI: 10.1002/chem.201502204]. This article may be used for non-commercial purposes in accordance with Wiley Terms and Conditions for Self-Archiving."

\title{
Lanthanide(II) Complexes Supported by N,O-Donor Tripodal Ligands: Synthesis, Structure and Ligand-Dependent Redox Behavior
}

\author{
Julie Andrez ${ }^{[a]}$, Gülay Bozoklu ${ }^{[b]}$, Grégory Nocton ${ }^{[b]}$, Jacques Pécaut ${ }^{[b]}$, Rosario Scopelliti ${ }^{[a]}$ Lionel $^{[}$ \\ Dubois $^{[b]}$ and Marinella Mazzanti ${ }^{*[a]}$
}

\begin{abstract}
The preparation and characterization of a series of complexes of the $\mathrm{Yb}$ and Eu cations in the oxidation state II and III with the tetradentate $\mathrm{O}, \mathrm{N}$ donor tripodal ligands TPA, BPA', BPPAand $\mathrm{MPA}^{2-}$ is reported. The $\mathrm{X}$-ray crystal structures of the heteroleptic $\mathrm{Ln}^{2+}$ complexes $\left[\mathrm{Ln}(\mathrm{TPA}) \mathrm{I}_{2}\right] \quad(\mathrm{Ln}=\mathrm{Eu}, \mathrm{Yb})$ and $\left[\mathrm{Yb}(\mathrm{BPA}) \mathrm{I}\left(\mathrm{CH}_{3} \mathrm{CN}\right)\right]_{2}$, of the $\mathrm{Ln}^{2+}$ homoleptic $\left[\mathrm{Ln}(\mathrm{TPA})_{2}\right] \mathrm{l}_{2}(\mathrm{Ln}=\mathrm{Sm}$, $\mathrm{Eu}, \mathrm{Yb})$ and $\left[\mathrm{Eu}(\mathrm{BPA})_{2}\right]$ complexes, and of the $\mathrm{Ln}^{3+}\left[\mathrm{Eu}(\mathrm{BPPA})_{2}\right] \mathrm{OTf}$ and $\left[\mathrm{Yb}(\mathrm{MPA})_{2} \mathrm{~K}(\mathrm{dme})_{2}\right]$ complexes have been determined. Cyclic voltammetry studies carried out on the bis-ligand complexes of $\mathrm{Eu}^{3+}$ and $\mathrm{Yb}^{3+}$ show that the metal center reduction occurs at significantly lower potentials for the BPA- ligand compared to the TPA ligand suggesting that the more electron-rich character of the BPA- ligand results in a higher reducing character of the lanthanide complexes of BPA $^{-}$compared to TPA. The important differences in the stability and reactivity of the investigated complexes are probably due to the observed difference in redox potential. Preliminary reactivity studies show that, while the bis-TPA complexes of $\mathrm{Eu}^{2+}$ and $\mathrm{Yb}^{2+}$ do not show any reactivity with heteroallenes the $\left[\mathrm{Eu}(\mathrm{BPA})_{2}\right]$ complex reduces $\mathrm{CS}_{2}$ affording the first example of a lanthanide trithiocarbonate complex.
\end{abstract}

\section{Introduction}

The molecular chemistry of $\mathrm{Eu}^{2+}, \mathrm{Yb}^{2+}$, and $\mathrm{Sm}^{2+}$ has been successfully used in a wide variety of applications and has afforded original reactivity. ${ }^{[1][2][3][4]}$ Furthermore, several examples of activation of small molecules such as $\mathrm{CO}_{2},{ }^{[5]} \mathrm{CS}_{2}{ }^{[5 c, 6]}$ and $\mathrm{N}_{2}{ }^{[7]}$ by $\mathrm{Ln}^{2+}$ complexes have been reported. Due to the recognized importance of steric and electronic factors in the control of $\mathrm{Ln}^{2+}$ reactivity ${ }^{[4 \mathrm{~b}-4 \mathrm{c}]}$ the association of the high reducing ability of

[a] J. Andrez, Dr. R. Scopelliti, Dr. M. Mazzanti Institut des Sciences et Ingénierie Chimiques Ecole Polytechnique Fédérale de Lausanne (EPFL), 1015 Lausanne (Switzerland) E-mail: marinella.mazzanti@epfl.ch

[b] Dr. G. Bozoklu, Dr. G. Nocton, Dr. J. Pécaut, Dr. L. Dubois Univ. Grenoble Alpes, INAC-SCIB, F-38000 Grenoble, France CEA, INAC-SCIB, F-38000 Grenoble, France

Supporting information for this article is given via a link at the end of the document. divalent lanthanides with a range of appropriate supporting ligands is crucial for establishing novel $\mathrm{Ln}^{2+}$ mediated transformations. Carbocyclic ligands $\left.{ }^{[1 \mathrm{c},} 4 \mathrm{~b}, 8\right]$ have been extensively and successfully used as supporting ligands in divalent lanthanide chemistry. However, reactivity studies associating $\mathrm{Ln}^{2+}$ with $\mathrm{O}$ or $\mathrm{N}$ donor chelating ligands are less developed. ${ }^{[2 b, 5 c, 5 d, 9] ~[6 a, 6 b] ~[10] ~ T r i p o d a l ~ p o l y p y r i d y l ~ l i g a n d s ~ s u c h ~ a s ~}$ $\operatorname{TPA}^{[11]}$ (Scheme 1) and tripodal aminephenolate ligands ${ }^{[12]}$ have been largely used as supporting ligands in d-block chemistry but they are rarer in $f$ element chemistry. ${ }^{[12-13]} \mathrm{Ln}^{3+}$ complexes of tripodal aminophenolates ${ }^{[12]}$ and of the TPA ligand ${ }^{[13 c, 13 d, 14]}$ have been reported and were shown to promote original stoichiometric and catalytic transformations. ${ }^{[15] ~[16] ~[17] ~ I n ~ c o n t r a s t ~}$ the complexation of divalent lanthanides by the TPA ligand has never been explored. Moreover, only a few examples of $\mathrm{Ln}^{2+}$ complexes of tripodal aminobisphenolates have been reported. ${ }^{[16,18]}$ Furthermore, while some of these complexes demonstrated attractive catalytic activity ${ }^{[16,18 a, 19]}$ and the ability of activating organic molecules, ${ }^{[18 a]}$ their reactivity with heteroallenes has not been investigated.

Recent results from our group show that electron-rich siloxide ligands can impart high reducing power to $\mathrm{Ln}^{2+}$ ions $(\mathrm{Ea}=-1.56 \mathrm{~V}$ for Yb-siloxide, $\mathrm{Ea}=-0.63 \mathrm{~V}$ for Eu-siloxide vs. $\mathrm{NHE})$, with relatively high $\mathrm{Ln}^{3+} / \mathrm{Ln}^{2+}$ redox potential $\left(\mathrm{E}_{1 / 2} \mathrm{Ln} 3+/ \mathrm{Ln} 2+\right.$ calculated for aqueous ions $=-0.35 \mathrm{~V}$ for $\mathrm{Eu}$ and $=-1.15$ for $\mathrm{Yb}$ vs. NHE and $E_{1 / 2}$ measured $=-0.05 \mathrm{~V}$ (Ybl2), 0.49V (Eul2) vsNHE) and promote unusual reactivity in homoleptic "ate" complexes of the classical lanthanide ions $\mathrm{Eu}^{2+}, \mathrm{Yb}^{2+} .^{[5 \mathrm{c}]}$ In the search for new ligand systems capable to promote higher reactivity in $\mathrm{Eu}^{2+}$, $\mathrm{Yb}^{2+}$ complexes, in this work, we investigate the influence of tripodal tetradentate ligands of different charge (Scheme 1) on the redox properties of the $\mathrm{Eu}^{2+}$ and, $\mathrm{Yb}^{2+}$ ions in homoleptic bisligand complexes.

Scheme 1. Targeted N- and O-donor tripodal ligands. 
<smiles>CC(C)N1C=CC=CN1CN(Cc1ccccn1)Cc1ccccn1</smiles><smiles>CC(C)(C)Cc1cc(C(C)(C)C)cc(CN(Cc2ccccn2)Cc2cc(C(C)(C)C)cc(C(C)(C)C)c2O)c1O</smiles>

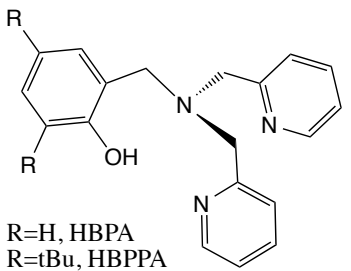

The previously reported tripodal tetradentate ligands presented in scheme 1, the neutral TPA (tris(2-pyridylmethyl)amine), ${ }^{[11]}$, the monoanionic $\mathrm{BPA}^{-} \quad$ (HBPA =bis(2-pyridylmethyl)(2hydroxybenzyl)amine) and BPPA ${ }^{-}$(HBPPA $=$bis $(2-$ pyridylmethyl) (3.5-di-tert-butyl-2-hydroxybenzyl)amine) ligands ${ }^{[13 \mathrm{~b}, 20]}$ and the dianionic $\mathrm{MPA}^{2-}$ ligand $\left(\mathrm{H}_{2} \mathrm{MPA}=(2-\right.$ pyridylmethyl)bis(3.5-di-tert-butyl-2-hydroxybenzyl)amine),, ${ }^{[21]}$ provide a series of analogous ligands with different charge which allow to investigate the effects of electronics on the stability and reactivity of divalent lanthanides. Here we report the first examples of heteroleptic mono-ligand and homoleptic bis-ligand complexes of TPA with the $\mathrm{Sm}^{2+}, \mathrm{Eu}^{2+}$ and $\mathrm{Yb}^{2+}$ ions. We also report the synthesis and crystal structure of the [Eu"(BPA $)_{2}$ ] complex and its reactivity with $\mathrm{CS}_{2}$. The redox properties of the bis-ligand complexes of $\mathrm{Eu}^{3+}$ and $\mathrm{Yb}^{3+}$ have been investigated for all the tetradentate ligands presented in scheme 1.

\section{Results and Discussion}

\section{TPA complexes}

The $\mathrm{Ln}^{2+}$ heteroleptic mono-ligand complexes $\left[\mathrm{Ln}(\mathrm{TPA}) \mathrm{I}_{2}\right.$ ] were obtained from the reaction of the divalent lanthanide iodide salts $\mathrm{Lnl}_{2}\left(\mathrm{Ln}=\mathrm{Sm}^{2+} \mathrm{Yb}^{2+} \mathrm{Eu}^{2+}\right)$ with one equivalent of TPA in THF. Crystals suitable for $\mathrm{X}$-ray diffraction of $\left[\mathrm{Yb}(\mathrm{TPA}) \mathrm{I}_{2}\left(\mathrm{CH}_{3} \mathrm{CN}\right)\right] \cdot\left(\mathrm{CH}_{3} \mathrm{CN}\right)_{0.5}$ and of $\left[\mathrm{Eu}(\mathrm{TPA})(\mu-\mathrm{I}) \mathrm{l}_{2}\right.$ were obtained by slow diffusion of diisopropylether into acetonitrile solutions of the $\mathrm{Yb}^{2+}$ and $\mathrm{Eu}^{2+}$ complexes.

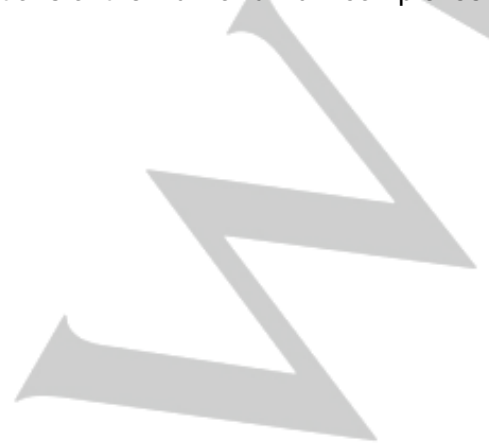

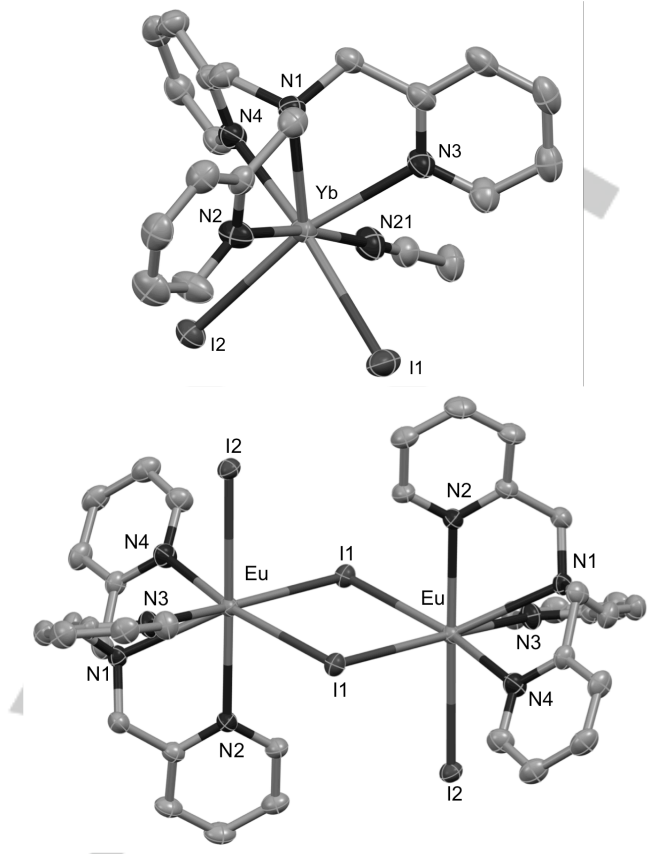

Figure 1. Ellipsoid diagram of the complex $\left[\mathrm{Yb}(\mathrm{TPA}) \mathrm{I}_{2}\left(\mathrm{CH}_{3} \mathrm{CN}\right)\right]$ (Top) and $[\mathrm{Eu}(\mathrm{TPA})(\mu-\mathrm{I})]_{2}$ (Bottom) (50\% probability ellipsoids). Hydrogen atoms and solvent molecules are omitted for clarity.

The complex $\left[\mathrm{Yb}(\mathrm{TPA}) \mathrm{I}_{2}\left(\mathrm{CH}_{3} \mathrm{CN}\right)\right] . \mathrm{CH}_{3} \mathrm{CN}_{0.5}$, crystallizes in the triclinic space group $\mathrm{P}-1$. A ellipsoid diagram of the complex is given in Figure 1 (Top). The metal ion is seven coordinated with a distorted monocapped octahedron geometry by four nitrogen atoms of TPA, two cis coordinated iodide ions and a nitrogen atom of an acetonitrile molecule. The coordination of the acetonitrile is nearly linear, with an $\mathrm{Yb}-\mathrm{N} 21-\mathrm{C} 21$ angle of $172.7(4)^{\circ}$. The triangular face N3, N2, N4 is capped by the N1 atom. The $\mathrm{Yb}-\mathrm{N}_{\text {amine }}$ bond $(2.620(4) \AA)$ is longer than the average $\mathrm{Yb}-\mathrm{N}_{\text {pyridyl }}$ bond $(2.565(6) \AA)$. The complex [Eu(TPA) $(\mu-$ I) I] $]_{2}$ crystallizes as a dimer in the orthorhombic Pbca space group (Figure 1 Bottom). The europium ion is situated $1.253 \AA$ above the plane defined by the $\mathrm{N}_{\text {pyridy }}$ atoms. This value is larger than one observed for the $\mathrm{Yb}^{2+}$ in $\left[\mathrm{Yb}(\mathrm{TPA}) \mathrm{I}_{2}\left(\mathrm{CH}_{3} \mathrm{CN}\right)\right](1.087 \AA)$ due to the smaller ionic radius of the $\mathrm{Yb}^{2+}$ ion compared to the $\mathrm{Eu}^{2+}$. These differences are probably responsible for the observed nuclearity of the $\mathrm{Yb}$ and Eu complexes in the solid state crystal structure. The structure has a $\mathrm{C}_{2}$ symmetry with a two-fold axis passing through the two bridging iodides. The europium atoms are seven coordinated, with a distorted mono capped octahedron geometry, by the four nitrogens of the TPA ligand, one terminal and two bridging iodide ligands. The ligand TPA adopts an helical arrangement around the metal cation as found in the in the $\mathrm{Eu}^{3+}$ complex $[\mathrm{Eu}(\mathrm{TPA})] \mathrm{Cl}_{3}{ }^{\left[{ }^{13 \mathrm{~d}]} \text { The average }\right.}$ Eu-N $N_{\text {pyridyl }}$ distance is $2.67(1) \AA$ and is significantly shorter than the Eu-Namine distance (2.748(3) $\AA$ ). Significantly shorter Eu-N distances were found in the $\mathrm{Eu}^{3+}$ complex $\left[\mathrm{Eu}(\mathrm{TPA}) \mathrm{CCl}_{3}{ }^{[13 \mathrm{~d}]}\right.$ (Eu$\mathrm{N}_{\text {amine }}=2.612(1) \AA$; mean Eu- $\mathrm{N}_{\text {pyridyl }}=2.57(2) \AA$ ) but the difference in bond length values remain smaller that the difference in ionic radii $(0.2 \AA) .{ }^{[2]}$ The Eu-I distance is shorter for 
the terminal iodide $(\mathrm{Eu}-\mathrm{I} 2=3.2888(3) \AA$ ) than for the bridging ones (Eu-l1 3.3142(1) $\AA$ and 3.3111(1) $\AA$ ).

Due to the strong paramagnetism of the $4 \mathrm{f}^{7}$ electronic configuration of $\mathrm{Eu}^{2+}$, no informative NMR spectrum could be obtained for the europium complexes. In contrast the ${ }^{1} \mathrm{H}$ NMR spectrum of the $\mathrm{Yb}^{2+}$ complex in deuterated acetonitrile shows a set of 5 (with two signals overlapping) signals in the diamagnetic region from 4.0 to $8.8 \mathrm{ppm}$ in agreement with the presence of dynamically averaged $\mathrm{C}_{3 \mathrm{v}}$ symmetric solution species. The [Eu(TPA $\left.) I_{2}\right]$ and $\left[\mathrm{Yb}(\mathrm{TPA}) \mathrm{I}_{2}\right]$ complexes are stable both in solid state and in acetonitrile solution. In contrast the [Sm(TPA) $\left.\left.\right|_{2}\right]$ complex is stable in the solid state but decomposes rapidly in acetonitrile solution preventing further characterization.

Thus, TPA has proven a suitable ligand for the synthesis of stable heteroleptic complexes of the $\mathrm{Eu}(\mathrm{II})$ and $\mathrm{Yb}(\mathrm{II})$ cations. Therefore, we also investigated the possibility of preparing homoleptic 2:1 complexes of TPA.

The $\mathrm{Ln}^{2+}$ homoleptic complexes $\left[\mathrm{Ln}(\mathrm{TPA})_{2}\right] \mathrm{l}_{2}(\mathrm{Ln}=\mathrm{Sm}, \mathrm{Yb}, \mathrm{Eu})$ have been obtained by reacting the divalent lanthanide iodide salts $\mathrm{Lnl}_{2}\left(\mathrm{Ln}=\mathrm{Sm}^{2+}, \mathrm{Yb}^{2+}, \mathrm{Eu}^{2+}\right)$ with two equivalents of TPA in THF at room temperature (Scheme 2). The isolated complexes have been characterized by ${ }^{1} \mathrm{H}$ NMR spectroscopy, X-ray crystallography and elemental analysis. Due to the very low solubility of these complexes in THF, crystals suitable for X-ray diffraction were obtained by slow diffusion of the ligand into a solution of $\mathrm{Lnl}_{2}$ in THF (for Eu, Sm) or by slow diffusion of DIPE into a concentrated solution of the complex in acetonitrile (for $\mathrm{Yb})$. The complexes $\left[\mathrm{Sm}(\mathrm{TPA})_{2}\right] \mathrm{I}_{2}$ and $\left[\mathrm{Eu}(\mathrm{TPA})_{2}\right] \mathrm{I}_{2}$ both crystallize in the monoclinic centrosymmetric $\mathrm{P}_{21 / c}$ space group. The complex $\left[\mathrm{Yb}(\mathrm{TPA})_{2}\right] \mathrm{l}_{2}$ crystallizes in the noncentrosymmetric monoclinic $\mathrm{C}_{\mathrm{c}}$ space group. The two complexes are isostructural and accordingly only the ellipsoid diagram of $\left[\mathrm{Sm}(\mathrm{TPA})_{2}\right]^{2+}$ is given in Figure 2 (top).

Scheme 2. Synthesis of $\left[\operatorname{Ln}(\operatorname{TPA})_{2}\right] \mathrm{I}_{2}$.

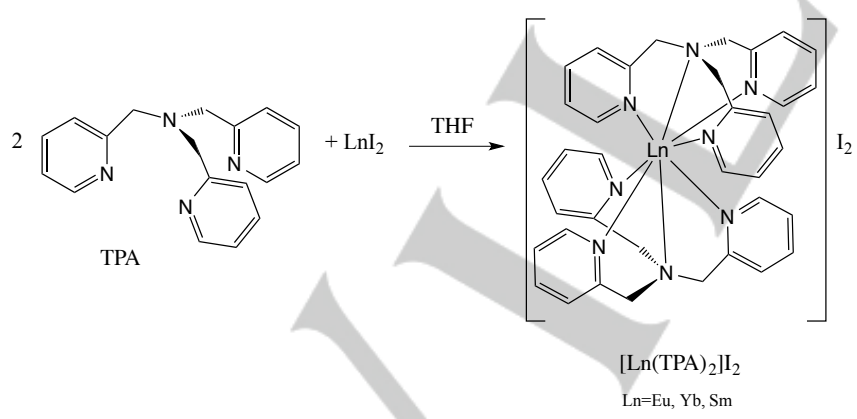

In the $\left[\operatorname{Ln}(T P A)_{2}\right]^{2+}$ complexes the metal cations are 8coordinated by the 8 nitrogens from the TPA ligands with a distorted cubic geometry. The angle between the two square faces is $1.46^{\circ}$ in the $\mathrm{Yb}$ complex [Yb(TPA $\left.\left.)_{2}\right]\right]_{2}$ while the two faces are perfectly parallel $\left(0^{\circ}\right)$ in the $\left[\operatorname{Sm}(\operatorname{TPA})_{2}\right] l_{2}$ and [Eu(TPA $\left.\left.)_{2}\right]\right]_{2}$ complexes resulting in a less distorted polyhedron. The N-N distances defining the edges of the cube range from $2.77 \AA$ to $3.48 \AA$ for $\left[\mathrm{Sm}(\mathrm{TPA})_{2}\right] \mathrm{l}_{2}, 2.77 \AA$ to $3.45 \AA$ for $\left[\operatorname{Eu}(\mathrm{TPA})_{2}\right] \mathrm{I}_{2}, 2.65 \AA$ to $3.38 \AA$ for $\left[\mathrm{Yb}(\mathrm{TPA})_{2}\right]_{2}$, and the angles within the cube described by the eight $\mathrm{N}$ atoms lie between $72.67^{\circ}$ and $96.19^{\circ}$ for $\left[\mathrm{Sm}(\mathrm{TPA})_{2}\right] \mathrm{l}_{2}, 73.28^{\circ}$ and $96.28^{\circ}$ for $\left[\mathrm{Eu}(\mathrm{TPA})_{2}\right] \mathrm{l}_{2}, 75.42^{\circ}$ and $97.12^{\circ}$ for $\left[\mathrm{Yb}(\mathrm{TPA})_{2}\right] \mathrm{l}_{2}$. The value of the $\mathrm{N}-\mathrm{Ln}-\mathrm{N}(\mathrm{Ln}=\mathrm{Sm}, \mathrm{Eu})$ trans angles is of $180^{\circ}$ as required by the presence of an inversion center symmetry in the $\left[\mathrm{Sm}(\mathrm{TPA})_{2}\right] \mathrm{l}_{2}$ and $\left[\mathrm{Eu}(\mathrm{TPA})_{2}\right]_{2}$ complexes. The mean value of the $\mathrm{Ln}-\mathrm{N}$ distances found for pyridyl nitrogen are 2.69(2) $\AA$ for $\left[\mathrm{Sm}(\mathrm{TPA})_{2}\right]_{2}, 2.67(2) \AA$ for $\left[\mathrm{Eu}(\mathrm{TPA})_{2}\right]_{\mathrm{l}_{2}}$, and $2.60(2) \AA$ for $\left[\mathrm{Yb}(\mathrm{TPA})_{2}\right] \mathrm{l}_{2}$. The mean value of the Ln-N distance found for the apical tertiary amine nitrogen is 2.730(8) $\AA, 2.727(3) \AA$, and 2.65(2) $\AA$ for the Sm, Eu and $\mathrm{Yb}$ complexes respectively (Table 1 and 2). Similarly to the previously reported trivalent analogues, ${ }^{[15 a]}$ the $\mathrm{Ln}-\mathrm{N}$ distances show a linear increase with increasing ionic radii as expected in a ionic bonding model and for ligands that can adapt well to metals of different sizes. In the structures of the $\left[\operatorname{Ln}(\text { TPA })_{2}\right]^{2+}$ complexes the two ligands show opposite right and left handed helical arrangement around the cation (Figure 2 bottom left). This differs from the structure of the previously reported $\mathrm{Ln}^{3+}$ complexes $\left.\left[\mathrm{Ln}(\mathrm{TPA})_{2}\right]_{3}\right]_{3} \quad\left(\mathrm{Ln}=\quad \mathrm{La}^{3+}, \quad \mathrm{Ce}^{3+}, \quad \mathrm{Nd}^{3+}\right)$, $\left[\mathrm{Eu}(\mathrm{TPA})_{2}\right]_{\mathrm{OTf}}{ }^{[15 \mathrm{a}]}$ and of the $\mathrm{U}^{3+}\left[\mathrm{U}(\mathrm{TPA})_{2}\right] \mathrm{l}_{2}{ }^{[13 \mathrm{a}]}$ complex where both ligands have the same helical arrangement Such difference in the ligand arrangement is probably the result of the larger ionic radius of the $\mathrm{Ln}^{2+}$ ions compared to the $\mathrm{Ln}^{3+}$ ones. Notably the same difference is also observed between the structure of $\left[\mathrm{Sm}(\mathrm{TPA})_{2}\right] \mathrm{l}_{2}$ and that of the $\mathrm{Sm}^{3+}$ complex $\left[\mathrm{Sm}(\mathrm{TPA})_{2}\right]_{3}$ (Figure 2 bottom right) prepared according to the procedure described for $\left[\mathrm{Ln}(\mathrm{TPA})_{2}\right]_{\mathrm{I}_{3}}$ complexes. ${ }^{[15 a]}$ The $\mathrm{Ln}-\mathrm{N}$ distances found in the $\left[\mathrm{Sm}(\mathrm{TPA})_{2}\right]_{3}\left(\mathrm{Sm}-\mathrm{N}_{\text {pyridine }}=2.55(3) \AA\right.$ and $\left.\mathrm{Sm}-\mathrm{N}_{\text {amine }}=2.59(2) \AA\right)$ are shorter than those found in $\left[\mathrm{Sm}(\mathrm{TPA})_{2}\right]_{2}\left(\mathrm{Sm}-\mathrm{N}_{\text {pyridine }}=\right.$ 2.69(2) $\AA$ and $S m-N_{a m i n e}=2.730(8) \AA$ ) in agreement with the difference in the ionic radii between $\mathrm{Sm}^{3+}(1.079 \AA)$ and $\mathrm{Sm}^{2+}$ $(1.27 \AA)^{[22]}$

The proton ${ }^{1} \mathrm{H}$ NMR spectra of the $\left.\left[\operatorname{Ln}(\mathrm{TPA})_{2}\right]\right]_{2}$ complexes $(\mathrm{Ln}=$ $\mathrm{Sm}^{2+}$ and $\mathrm{Yb}^{2+}$ ) in $\mathrm{CD}_{3} \mathrm{CN}$ shows the presence of one set of signals with four resonances for the pyridyl protons and a single resonance for the methylene protons both at room temperature and at low temperature $(283 \mathrm{~K})$ in agreement with the presence of dynamically averaged $D_{3}$ h symmetric solution species in which all chelating arms of the TPA ligand are equivalent. The complex $\left[\mathrm{Sm}(\mathrm{TPA})_{2}\right]_{2}$ is insoluble in THF and unstable at room temperature in acetonitrile. After one day, the color of the acetonitrile solution turned from blue green to yellow and only unidentified decomposition products are found in solution. 

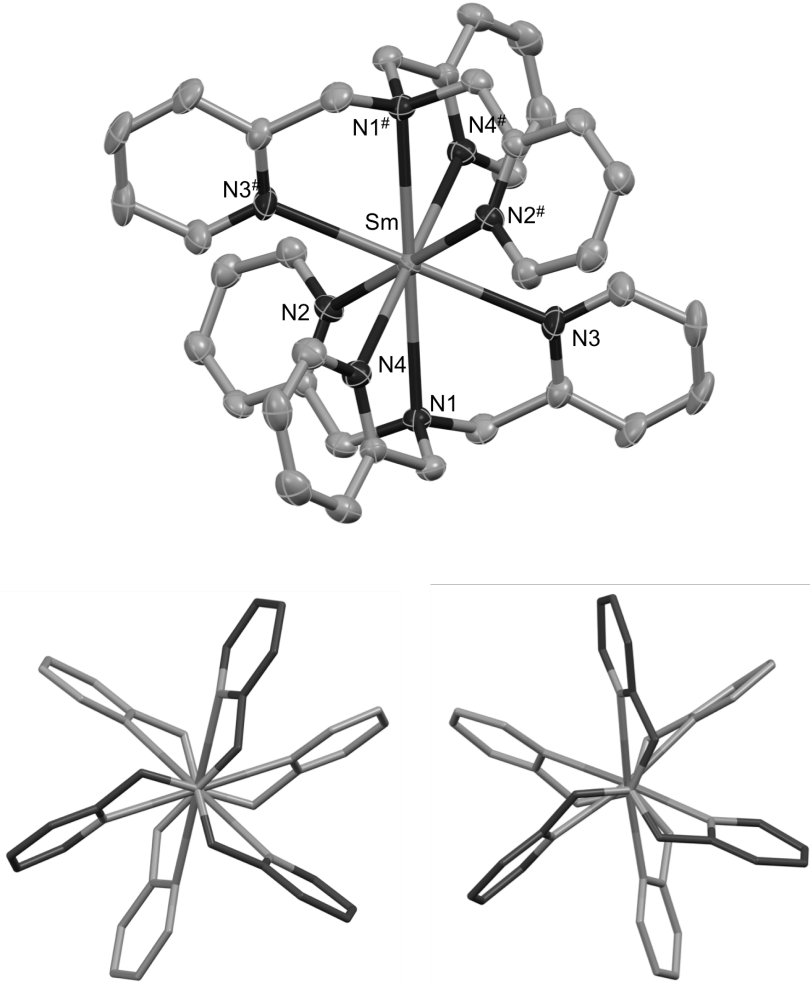

Figure 2. Ellipsoid diagram of $\left[\mathrm{Sm}(\mathrm{TPA})_{2}\right]^{2+}$ (top)(50\% probability ellipsoids). Hydrogen atoms and iodine counter-ion are omitted for clarity. $\left({ }^{\#}=-x+1,-y+1,-\right.$ $z+1$ ). Ellipsoid diagram of the structures $\left[\operatorname{Sm}(T P A)_{2}\right] l_{2}$ (bottom left) and $\left[\mathrm{Sm}(\mathrm{TPA})_{2}\right]_{3}$ (bottom right), $\mathrm{S}_{6}$ and $\mathrm{D}_{3}$ symmetric arrangement respectively. Hydrogen atoms and iodine counter-ion are omitted for clarity.

The complexes $\left[\mathrm{Yb}(\mathrm{TPA})_{2}\right]_{2}$ and $\left[\mathrm{Eu}(\mathrm{TPA})_{2}\right]_{2}$ are stable for weeks in acetonitrile at room temperature. The higher solution stability compared to the $\mathrm{Sm}^{2+}$ analogue is in agreement with the less negative $\mathrm{Ln}^{3+} / \mathrm{Ln}^{2+}$ redox potential of $\mathrm{Eu}$ and $\mathrm{Yb}$ ions $(-0.35$ $V$ and -1.15 vs. NHE respectively) compared to that of Sm (-1.55 vs. NHE) and with the electrochemistry studies carried out on the homoleptic complexes (see electrochemistry section).

In order to investigate how the charge and electron-donor character of the ligand affects the redox properties and reactivity of $\mathrm{Ln}^{2+}$ ions we have studied the complexation of $\mathrm{Yb}$ and $\mathrm{Eu}$ in the oxidation state $+\mathrm{III}$ and $+\mathrm{II}$ by the monoanionic tetradentate ligands $\mathrm{BPA}^{-}$and $\mathrm{BPPA}^{-}$and by the dianionic $\mathrm{MPA}^{2-}$ ligands. Due to their low solution stability we did not attempt the study of the analogous BPA and BPPA- complexes of $\mathrm{Sm}^{2+}$.

\section{BPA complexes}

The $\left[\mathrm{Ln}(\mathrm{BPA})_{2}\right] \mathrm{OTf}$ complexes $(\mathrm{Ln}=\mathrm{Eu}, \mathrm{Yb})$ were prepared in situ for electrochemistry studies by reacting the trivalent lanthanide salts $\operatorname{Ln}(\mathrm{OTf})_{3}$ with 2 equivalents of the KBPA ligand in acetonitrile (Scheme 2). The $\mathrm{Eu}^{3+}$ complex [Eu(BPA) 2 ]OTf was also prepared and characterized. Orange crystals suitable for $X$ ray diffraction were obtained from a slow diffusion of DIPE into a THF solution of the complex.
Scheme 2. Synthesis of $\left[\mathrm{Eu}(\mathrm{BPA})_{2}\right]$ and $\left[\operatorname{Ln}(\mathrm{BPA})_{2}\right] \mathrm{OTf}$ complexes.

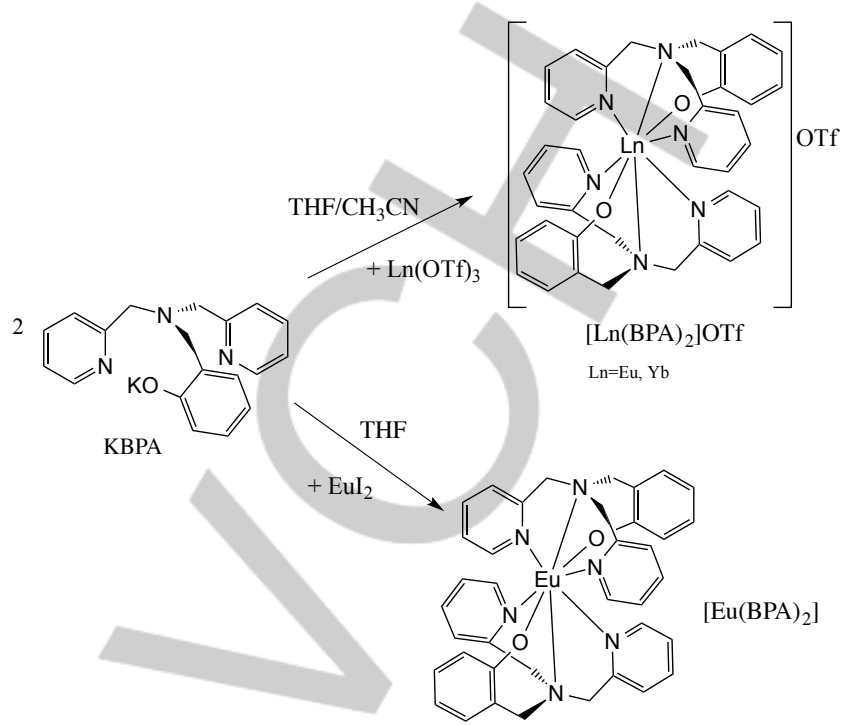

[Eu(BPA $\left.)_{2}\right]$ OTf crystallizes in the monoclinic $P_{21 / n}$ space group. The structure presents an octacoordinated europium surrounded by two BPA ligands in a distorted dodecahedral fashion (Figure 3 left). Similar values are found for the average Eu- $\mathrm{N}_{\text {pyridyl }}$ bond distances (mean value $=2.62(3) \AA$ ) and the Eu-Namine distance (2.64(5) $\AA$ ). The mean value of the Eu-O distances is 2.234(8) $\AA$ and fall in the range of Eu- $\mathrm{O}_{\text {phenoxide }}$ bond distances reported in the literature. ${ }^{[23]}$ The two ligands BPA wrap around the $\mathrm{Eu}^{3+}$ cation with a pincer arrangement rather than the helical one found in bis-TPA complexes (Figure 3). The ${ }^{1} \mathrm{H}$ NMR spectrum of the complex in $\mathrm{CD}_{3} \mathrm{CN}$ shows a set of very broad signals for the $18 \mathrm{H}$ from 31 to $-18 \mathrm{ppm}$.

The reaction of the divalent $\mathrm{Eul}_{2}$ salt with 2 equivalents of the KBPA ligand in THF leads to isolation of the neutral homoleptic $\mathrm{Eu}^{2+}$ complex [Eu(BPA)2] (Scheme 2). The complex has very low solubility in THF but is partially soluble in acetonitrile and pyridine and is stable in the three solvents for several weeks. The paramagnetism of the $\mathrm{Eu}^{2+}$ ion leads to an uninformative ${ }^{1} \mathrm{H}$ NMR spectrum. Suitable single crystals were obtained from slow diffusion of hexane into a pyridine solution of the complex. The $X$-ray diffraction studies show the presence of the bis-ligand complex [Eu(BPA)2], which crystallize in monoclinic system and $P_{21 / n}$ space group. The overall neutral charge is in agreement with the presence of an $\mathrm{Eu}^{2+}$ cation. The octacoordinated europium is surrounded by two ligands in a distorted cubic fashion (Figure 3 right). The two ligands wrap around the metal ion in a geometry that brings the two oxygen atoms from the phenolate arms side by side. In each ligand, a Eu- $\mathrm{N}_{\text {pyridyl }}$ distance is significantly shorter than the other: $2.755(3) \AA$ and 2.866(3) for the first ligand, 2.742(3) and 2.887(3) $\AA$ for the second one. These distances are slightly elongated compared to the bis-TPA europium complex where the average Eu- $\mathrm{N}_{\text {pyridyl }}$ is 2.68(2) $\AA$. This is probably due to the steric effect of the phenol arms. The average value of the Eu- $N_{a m i n e} 2.83(5) \AA$ is $0.1 \AA$ longer than the value found for the bis-ligand complexes $\left[\mathrm{Eu}(\mathrm{TPA})_{2}\right]_{2}$. The large lengthening of the Eu-N and Eu-O $(2.83(5) \AA)$ distances found in the [Eu(BPA $)_{2}$ ] compared to the 
$\mathrm{Eu}^{3+}$ analogue can be interpreted in term of the difference in ionic radii of the $\mathrm{Eu}^{3+}$ and $\mathrm{Eu}^{2+}$ cations $(0.19 \AA)$. $^{[22]}$ The two ligands in the $\mathrm{Eu}^{2+}$ complex adopt the same helical conformation leading to a chiral complex. Both enantiomers $\Lambda \Lambda$ and $\Delta \Delta$ are present in the structure.
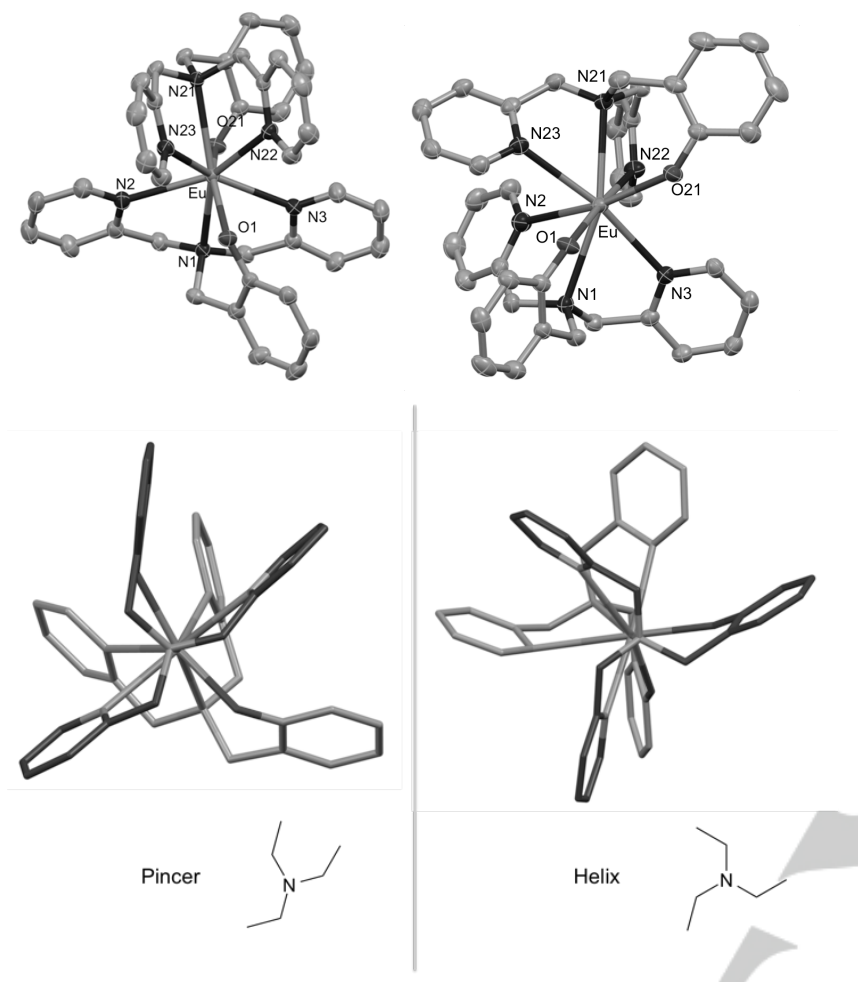

Figure 3. Ellipsoid diagrams of $\left[\mathrm{Eu}(\mathrm{BPA})_{2}\right]^{+}$(left) and $\left[\mathrm{Eu}(\mathrm{BPA})_{2}\right]$ (right) $(50 \%$ probability ellipsoids). Hydrogen atoms and triflate counter-ion of $\left[\mathrm{Eu}(\mathrm{BPA})_{2}\right]^{+}$ are omitted for clarity.

Attempts to isolate single crystals of the $\mathrm{Yb}^{2+}\left[\mathrm{Yb}(\mathrm{BPA})_{2}\right]$ complex failed due to the low stability of this species at $-40^{\circ} \mathrm{C}$. Proton NMR studies of the reaction of $\mathrm{Ybl}_{2}$ with two equivalents of the KBPA ligand salt in THF at $233 \mathrm{~K}$ or at room temperature shows the presence of a complicated mixture of paramagnetic species while proton NMR studies of the reaction of $\mathrm{Ybl}_{2}$ with two equivalents of the KBPA ligand salt in acetonitrile at $233 \mathrm{~K}$ show paramagnetic signals assigned to the $\mathrm{Yb}^{3+}\left[\mathrm{Yb}(\mathrm{BPA})_{2}\right]^{+}$ complex. Signals of intermediate diamagnetic species are also observed immediately after mixing the $\mathrm{Ybl}_{2}$ and the ligand, but these species decompose even at $233 \mathrm{~K}$. After 1 night at room temperature or at $233 \mathrm{~K}$, the THF and acetonitrile reaction mixture became deep blue. The deep blue color of the reaction mixture after complete decomposition is suggestive of the presence of additional reaction products since the $\left[\mathrm{Yb}(\mathrm{BPA})_{2}\right]^{+}$ complex is colorless. The formation of $\left[\mathrm{Yb}(\mathrm{BPA})_{2}\right]^{+}$could arise from a disproportionation reaction of a $\mathrm{Yb}^{2+}$ intermediate species to $\mathrm{Yb}^{3+}$ and $\mathrm{Yb}^{0}$ or from solvent/ ligand reduction. Notably $\mathrm{C}-\mathrm{C}$ coupling of aromatic heterocycles by $\mathrm{Yb}^{2+}$ complexes has been previously reported. ${ }^{[3 c]}$ Attempts to isolate potential additional decomposition products were not successful.

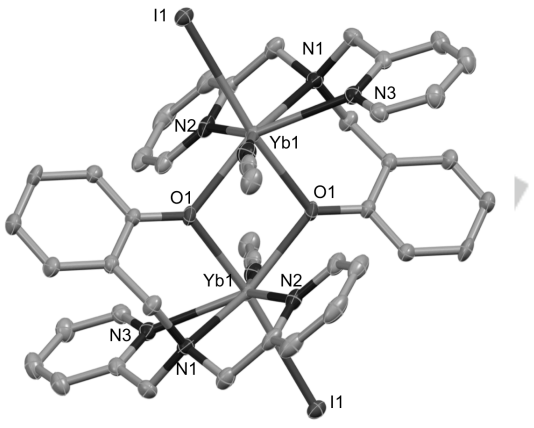

Figure 4. Ellipsoid diagrams of $\left[\mathrm{Yb}(\mathrm{BPA}) \mathrm{I}\left(\mathrm{CH}_{3} \mathrm{CN}\right)\right]_{2} \quad(50 \%$ probability ellipsoids). Hydrogen atoms and solvent molecule are omitted for clarity.

These results indicate that the replacement of one pyridine of the TPA ligand with a phenol group reduces significantly the stability of the respective homoleptic $\mathrm{Yb}^{2+}$ complexes compared to their $\mathrm{Yb}^{3+}$ analogues. The difference in stability of the $\left[\mathrm{Eu}(\mathrm{BPA})_{2}\right]$ and of the $\left[\mathrm{Yb}(\mathrm{BPA})_{2}\right]$ complexes can be explained by the difference in redox potential between the two cations (see electrochemistry section).

However, the proton NMR in $\mathrm{CD}_{3} \mathrm{CN}$ of a solution of $\mathrm{Ybl}_{2}$ reacted with one equivalent of BPA ligand shows the presence of only one set of signals in the diamagnetic region, in agreement with the formation of a stable heteroleptic $\mathrm{Yb}^{2+}$ complex. Indeed, the complex $\left[\mathrm{Yb}(\mathrm{BPA}) \mid\left(\mathrm{CH}_{3} \mathrm{CN}\right)\right]_{2}$ (Figure 4) crystallizes from a saturated acetonitrile solution in the $P_{21 / n}$ space group. The crystals structure of the $\mathrm{Yb}^{2+}$ mono-BPA complex shows that the phenolate oxygen atoms of the ligand BPA bridge two $\mathrm{Yb}^{2+}$ ions affording a dimer with an inversion center in the middle of the YbOOYb diamond core (Figure 4). The two $\mathrm{Yb}$ ions are heptacoordinated by three nitrogen and two oxygen atoms from the BPA ligands, one nitrogen from an acetonitrile molecule and one iodide with a distorted pentagonal bipyramidal geometry. The value of the $\mathrm{Yb}-\mathrm{Namine}$ distance $(2.594(3) \AA)$ and the average value of the $\mathrm{Yb}-\mathrm{N}_{\text {pyridyl }}$ distance (2.626(9) $\AA$ ) are similar to those found for the $\mathrm{Yb}-\mathrm{N}_{\text {amine }}$ and $\mathrm{Yb}$ $\mathrm{N}_{\text {pyridyl }}$ distances in the $\left[\mathrm{Yb}(\mathrm{TPA}) \mathrm{I}_{2} \mathrm{CH}_{3} \mathrm{CN}\right]$ and $\left[\mathrm{Yb}(\mathrm{TPA})_{2} \mathrm{I}_{2}\right]$ complexes. The $\mathrm{Yb}-\mathrm{O}$ distances is $2.346(3) \AA$ and falls in the range of bridging $\mathrm{Yb}-\mathrm{O}_{\text {phenoxide }}$ bond distances reported in literature. ${ }^{[16]}$

These results suggest that, in spite of its more electron rich character compared to TPA, the BPA ligand can be used in the preparation of stable heteroleptic complexes of divalent ytterbium. Future studies will be directed to investigate the reactivity and catalytic activity of this compound.

\section{BPPA complexes}

The $\left[\mathrm{Ln}(\mathrm{BPPA})_{2}\right] \mathrm{OTf}$ complexes $(\mathrm{Ln}=\mathrm{Eu}, \mathrm{Yb})$ were prepared in situ for electrochemistry studies by reacting the trivalent lanthanide salt $\operatorname{Ln}(\mathrm{OTf})_{3}$ with 2 equivalents of the KBPPA ligand in acetonitrile (Scheme 3). The $\mathrm{Eu}^{3+}$ complex [Eu(BPPA)2]OTf was also isolated and characterized. The complex is partially soluble in THF but fully soluble in acetonitrile. The ${ }^{1} \mathrm{H}$ NMR spectrum of this complex in $\mathrm{CD}_{3} \mathrm{CN}$ shows $34 \mathrm{H}$ broad and sharp 
signals in the range -15 to $+23 \mathrm{ppm}$. The quality of the X-ray data collected for the orange needles obtained by a slow diffusion of hexane into a pyridine solution of the complex was good enough to establish the overall structure and connectivity (Figure 5) but insufficient to allow the discussion of the bond distances.

Scheme 3. Synthesis of $\left[\operatorname{Ln}(B P P A)_{2}\right]$ OTf complexes.

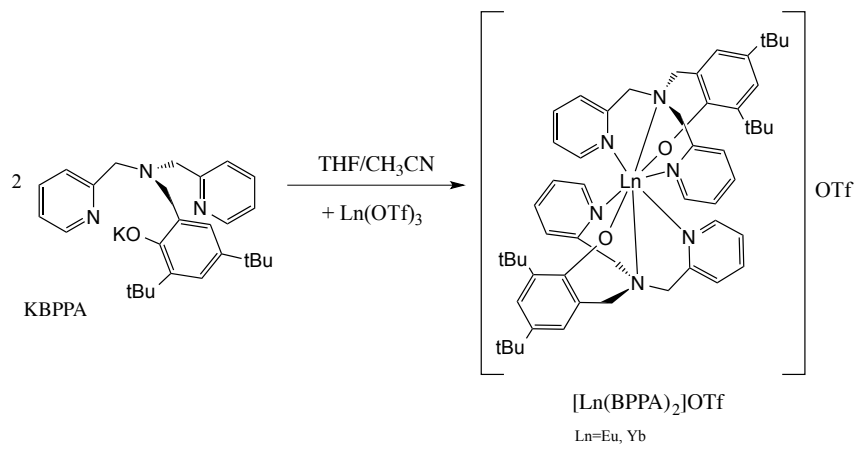

The crystal structure shows that the europium center is octacoordinated by two tetradentate BPPA ligands with a distorted cubic geometry. The ligand arms are both in a helical conformation presenting opposite rotation direction. This results in an achiral complex. The overall monocationic charge of the $\mathrm{Eu}^{3+}$ complex is counterbalanced by the triflate anion. The structure of the $\left[\mathrm{Eu}(\mathrm{BPPA})_{2}\right] \mathrm{OTf}$ complex shows that the presence of the bulky tertbutyl substituents do not prevent formation of homoleptic bis-ligand complexes.

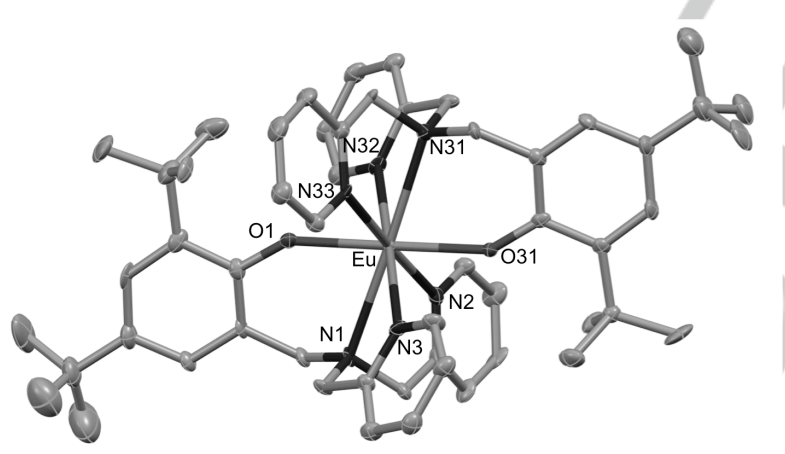

Figure 5. Ellipsoid diagrams of [Eu(BPPA) 2 ]OTf (50\% probability ellipsoids). Hydrogen atoms, solvent molecules, disorder and triflate counter anion are omitted for clarity.

\section{MPA complexes}

Proton NMR studies in $\mathrm{CD}_{3} \mathrm{CN} / \mathrm{THF}$ of the reaction of the trivalent lanthanide salts $\mathrm{Ln}(\mathrm{OTf})_{3}(\mathrm{Ln}=\mathrm{Eu}, \mathrm{Yb})$ with 1 or 2 equivalents of the $\mathrm{K}_{2} \mathrm{MPA}$ ligand show the formation of the bisligand complex independently of the used stoichiometry (Scheme 4). This suggests a strong preference of the MPA ${ }^{2-}$ for the formation of 2:1 complexes, a behavior rarely encountered in coordination chemistry ${ }^{[24]}$ but previously reported for $\mathrm{Nd}^{3+}$ complexes of aminobis-phenolates. ${ }^{[17 d]}$ The bis-ligand "ate" complex $\left[\mathrm{Yb}(\mathrm{MPA})_{2} \mathrm{~K}\right]$ was isolated from the reaction of $\mathrm{Yb}(\mathrm{OTf})_{3}$ with 2 equivalents of the $\mathrm{K}_{2}$ MPA ligand in THF. The presence of the tert-butyl groups renders the final complex very soluble in non-polar solvents such as hexane. Colorless crystals suitable for X-ray diffraction of the complex $\left[\mathrm{Yb}(\mathrm{MPA})_{2} \mathrm{~K}(\mathrm{dme})_{2}\right]$ were obtained from a concentrated solution of the complex in hexane/dme (30:1) at $233 \mathrm{~K}$. The X-ray crystal structure (Figure 6 ) shows that two MPA ligands bind to the $\mathrm{Yb}^{3+}$ ion, but in the resulting complex the pyridine nitrogens remain not binding with a Ln-N distance of 5.393(19) $\AA$.

Scheme 4. Synthesis of $\left[\mathrm{Ln}(\mathrm{MPA})_{2} \mathrm{~K}\right]$ complexes.

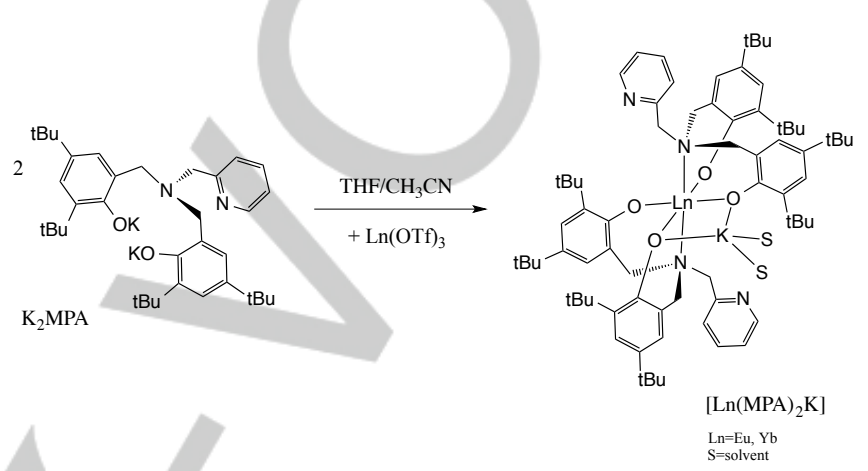

As a result the ytterbium center is only hexacoordinated by two MPA ligands in a distorted octahedral fashion. The average values of the $\mathrm{Yb}-\mathrm{O}$ distance and of the $\mathrm{Yb}-\mathrm{N}_{\text {amine }}$ distance are respectively 2.16(2) $\AA$ and $2.448(16)$ and are slightly shorter than the $\mathrm{Yb}-\mathrm{O}$ and $\mathrm{Yb}-\mathrm{Namine}$ average distances of the divalent $\mathrm{Yb}$ complex $\left[\mathrm{Yb}(\mathrm{BPA}) \mathrm{I}\left(\mathrm{CH}_{3} \mathrm{CN}\right)\right]_{2}$. This is in agreement with the shorter ionic radii of $\mathrm{Yb}(\mathrm{III})$ center (Table 2). A potassium cation is also present in the structure binding a phenolate oxygen from each ligand with a K-O distance of $2.794(14) \AA$. The K coordination sphere is completed by two dme molecules. The ${ }^{1} \mathrm{H}$ NMR spectrum of $\left[\mathrm{Yb}(\mathrm{MPA})_{2} \mathrm{~K}\right]$ in $\mathrm{CD}_{3} \mathrm{CN}$ shows the presence of paramagnetically shifted signals in the $-50-+186 \mathrm{ppm}$ range, indicative of $\mathrm{Y} \mathrm{Yb}^{3+}$ metal centre.

While X-ray suitable crystals of the $\left[\mathrm{Eu}(\mathrm{MPA})_{2} \mathrm{~K}\right]$ complex were not obtained, the ${ }^{1} \mathrm{H}$ NMR spectrum of a 1:2 solution of Eul ${ }_{2}$ and $\mathrm{K}_{2} \mathrm{MPA}$ in $\mathrm{CD}_{3} \mathrm{CN}$ only shows one set of paramagnetically shifted signals in the -9 to $+10 \mathrm{ppm}$ range.

Table 1. Selected average bond distances $(\AA)$ for Eu complexes.

\begin{tabular}{|c|c|c|c|c|c|}
\hline Bonds & $\begin{array}{c}{\left[E u^{\prime \prime}(T P A)(\right.} \\
\mu-I) I]_{2}\end{array}$ & [Eu"(TPA) $\left.)\left._{2}\right|_{2}\right]$ & [Eu"(BPA)2] & $\begin{array}{c}{\left[\mathrm{Eu}^{\mathrm{III}}(\mathrm{BPA})_{2}\right.} \\
\text { ]OTf }\end{array}$ & $\begin{array}{l}{\left[\mathrm{Eu}^{\mathrm{III}}(\mathrm{BPA})\right.} \\
\left(\mathrm{CS}_{3}\right) \\
\left.(\mathrm{DMSO})_{2}\right]\end{array}$ \\
\hline $\begin{array}{l}\text { Eu- } \\
\text { Namine }\end{array}$ & $2.748(3)$ & $2.731(3)$ & $2.83(5)$ & $2.64(5)$ & $2.674(8)$ \\
\hline $\begin{array}{l}\text { Eu- } \\
\text { Npyridyl }\end{array}$ & $2.67(1)$ & $2.68(2)$ & $\begin{array}{c}2.749(9) \\
\text { and } \\
2.88(1)\end{array}$ & $2.62(3)$ & $2.61(1)$ \\
\hline Eu-O & I & I & $2.41(3)$ & $2.234(8)$ & $2.273(7)$ \\
\hline
\end{tabular}


Table 2. Selected average bond distances $(\AA)$ for $\mathrm{Yb}$ complexes.

\begin{tabular}{ccccc}
\hline Bonds & $\begin{array}{c}{\left[\mathrm{Yb}^{\prime \prime}(\mathrm{TPA}) \mathrm{I}_{2}\right.} \\
\left.\left(\mathrm{CH}_{3} \mathrm{CN}\right)\right]\end{array}$ & {$\left[\mathrm{Yb}^{\prime \prime}(\mathrm{TPA})_{2} \mathrm{I}_{2}\right]$} & $\begin{array}{c}{\left[\mathrm{Yb}^{\prime \prime}(\mathrm{BPA}) \mathrm{I}\right.} \\
\left.\left(\mathrm{CH}_{3} \mathrm{CN}\right)\right]_{2}\end{array}$ & $\begin{array}{c}\mathrm{Y} b^{\prime \prime \prime}(\mathrm{MPA}) \mathrm{K} \\
\left.(\mathrm{dme})_{2}\right]\end{array}$ \\
\hline $\begin{array}{c}\mathrm{Yb}- \\
\mathrm{N}_{\text {amine }}\end{array}$ & $2.620(4)$ & $2.65(3)$ & $2.594(3)$ & $2.448(16)$ \\
$\begin{array}{c}\mathrm{Yb}- \\
\mathrm{N}_{\text {pyridyl }}\end{array}$ & $2.565(6)$ & $2.68(2)$ & $2.626(9)$ & $/$ \\
$\mathrm{Yb}-\mathrm{O}$ & $/$ & $/$ & $2.346(3)$ & $2.16(2)$ \\
\hline
\end{tabular}

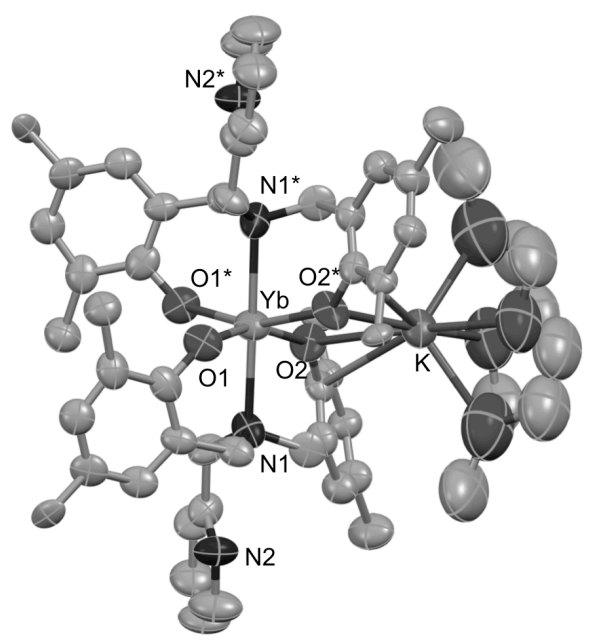

Figure 6. Ellipsoid diagram of $\left[\mathrm{Yb}(\mathrm{MPA})_{2} \mathrm{~K}(\mathrm{dme})_{2}\right]$ ( $50 \%$ probability ellipsoids). Hydrogen atoms, solvent molecules and methyl groups are omitted for clarity. $*=y, x,-z$.

${ }^{1} \mathrm{H}$ NMR studies of the reaction of $\mathrm{Ybl}_{2}$ with one equivalent of $\mathrm{K}_{2} \mathrm{MPA}$ in THF at $233 \mathrm{~K}$ show the formation of a diamagnetic species assigned to the [Yb(MPA)] complex (Figure S.A.12). A broad uninformative proton NMR spectrum is obtained for the reaction of Eul 2 with one equivalent of $\mathrm{K}_{2} \mathrm{MPA}$ in THF at $233 \mathrm{~K}$ suggesting the presence of the $\mathrm{Eu}^{2+}$ ion. The neutral [Ln(MPA)] complexes are stable in THF at room temperature, but the addition of small ligand excess leads in both cases to the apparition of the paramagnetic signals of the $\mathrm{Eu}^{3+}$ and $\mathrm{Yb}^{3+}$ complexes. Stable mono-ligand complexes of $\mathrm{Yb}^{2+}$ with bulky aminobisphenolate (tertButyl substituents on the phenolate groups) containing a methoxy ${ }^{[16,19 a]}$ or a dimethylamine $\operatorname{arm}^{[18 a]}$ have been previously reported and proven active catalysts in ring-opening polymerization of cyclic esters. ${ }^{[16,18 a, 19 a]}$ Attempts to isolate crystal of the neutral [Ln(MPA)] complexes suitable for X-ray diffraction were not successful so far. However, NMR studies suggest that the presence of a pyridyl arm does not lead to a decreased stability of the mono-ligand $\mathrm{Yb}^{2+}$ complexes compared to the methoxy and dimethylamino arms.

The reaction of the divalent $\mathrm{Eul}_{2}$ salt with two equivalents of $\mathrm{K}_{2} \mathrm{MPA}$ in THF at $233 \mathrm{~K}$ leads to the formation of intermediate
$\mathrm{Eu}^{2+}$ species which decompose slowly to afford the $\mathrm{Eu}^{3+}$ complex $\left[\mathrm{Eu}(\mathrm{MPA})_{2} \mathrm{~K}\right]$ as identified by NMR spectroscopy. ${ }^{1} \mathrm{H}$ NMR studies of the 1:2 $\mathrm{Ybl}_{2}: \mathrm{K}_{2} \mathrm{MPA}$ reaction in THF at $233 \mathrm{~K}$ show the immediate formation of the $\mathrm{Yb}^{3+}$ complex [Yb(MPA) ${ }_{2} \mathrm{~K}$ ], which was also identified by $\mathrm{X}$-ray diffraction studies. The formation of the $\left[\mathrm{Ln}(\mathrm{MPA})_{2} \mathrm{~K}\right]$ compounds could arise from a disproportionation process affording the $\mathrm{Ln}^{3+}$ bis-ligand complexes and $\mathrm{Ln}^{0}$ (not unambiguously identified), or from solvent/ ligand reduction.

The formation of a bis-ligand complex of $\mathrm{Yb}^{3+}$ has also been observed for the reaction of the $\mathrm{Ybl}_{2}$ or the $\left[\mathrm{Yb}\left(\mathrm{N}\left(\mathrm{SiMe}_{3}\right)_{2}\right)_{2}\right]$ precursors with tripodal aminobisphenolate ligands containing a methoxide $\operatorname{arm}^{[18 \mathrm{c}]}$ or a dimethylamine arm. ${ }^{[16]}$

The presented results show that the replacement of two pyridyl groups in the TPA ligand with two phenoxide groups prevents the formation of stable homoleptic bisligand complexes for both the $\mathrm{Yb}^{2+}$ and $\mathrm{Eu}^{2+}$ ions.

In order to relate the stability properties of the described complexes to their redox properties, cyclic voltammetry studies were carried out on the homoleptic complexes of the ligands TPA, BPA, BPPA and MPA.

\section{Electrochemistry Studies}

Cyclic voltammograms were measured in acetonitrile on samples of the trivalent complexes $\left[\mathrm{Yb}(\mathrm{TPA})_{2} \mathrm{OTf}_{3}\right.$ and [Eu(TPA $\left.)_{2}\right]_{O T f}$ (Figure 7) prepared in situ. These data clearly show the quasi-reversible reduction of the metal center at $E_{1 / 2}=-$ $1.11 \mathrm{~V}$ and $-0.41 \mathrm{~V}$ vs $\mathrm{Fc}^{+} / \mathrm{Fc}$, respectively. The cyclic voltammograms of the Sm complex [Sm(TPA $\left.)_{2}\right]_{\mathrm{OTf}}$ prepared in situ shows an irreversible reduction of the metal center at $-1.7 \mathrm{~V}$ vs $\mathrm{Fc}^{+} / \mathrm{Fc}$ (Figure S.C.2). The irreversible character of this event is in agreement with the instability of the divalent $\mathrm{Sm}$ complex $\left[\mathrm{Sm}(\mathrm{TPA})_{2}\right]^{2+}$ in acetonitrile. The cyclic voltammogram of the free ligand (see supporting info) confirms the absence of redox events at these potentials when the metal ions are missing. The voltammogram of the free ligand also presents an irreversible oxidation feature at $E_{p a}=0.63 \mathrm{~V}$ which is attributed to the oxidation of the central tertiary amine. This event is absent in the voltammogram of $\left[\mathrm{Eu}(\mathrm{TPA})_{2}\right] \mathrm{OTf}$. The coordination of the amine to the metal center probably renders its oxidation more difficult resulting in a shift of this wave from $0.63 \mathrm{~V}$ to higher potentials.

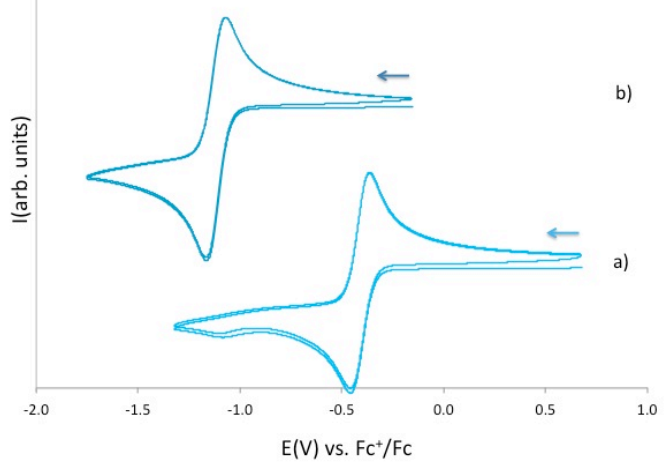


Figure 7. Cyclic voltammogram for $4 \mathrm{mM}$ solutions of a) $\left.\left[\mathrm{Eu}(\mathrm{L} 1)_{2}\right] \mathrm{OTf} b\right)$ $\left[\mathrm{Yb}(\mathrm{L} 1)_{2}\right] \mathrm{OTf}$ in $\sim 0.1 \mathrm{M}\left[\mathrm{Bu}_{4} \mathrm{~N}\right]\left[\mathrm{PF}_{6}\right]$ acetonitrile solution at $100 \mathrm{mV} . \mathrm{s}^{-1} \mathrm{scan}-$ rate.

In order to investigate the impact of the presence of phenolate oxygen donors on the redox properties of their $\mathrm{Yb}^{2+}$ and $\mathrm{Eu}^{2+}$ complexes we studied the redox properties of the analogous BPA and MPA complexes.

The cyclic voltammograms obtained in acetonitrile solutions of the trivalent complex [Yb(BPA) 2 OTf prepared in situ show an irreversible reduction of the metal center at the very low potential of $-2.41 \mathrm{~V}$ ( $\mathrm{vs} \mathrm{Fc}^{+} / \mathrm{Fc}$ ) close to the reduction of the solvent (Figure 8-b). This reduction does not become reversible even at $1 \mathrm{~V} / \mathrm{s}$ scan rate suggesting that a highly reactive $\mathrm{Yb}^{2+}$ species is formed. Notably, a shift to more negative potentials of the metal center reduction process is observed for both [Yb(BPA) 2 ] $\mathrm{OTf}$ and $\left[\mathrm{Eu}(\mathrm{BPA})_{2}\right] \mathrm{OTf}$ complexes compared to the TPA analogous complexes (from $E_{p c}=-1.17 \mathrm{~V}$ to $E_{p c}=-2.41 V$ i.e. $-1.24 \mathrm{~V}$ shift for $\mathrm{Yb}$ and from $\mathrm{E}_{1 / 2}=-0.48 \mathrm{~V}$ to $\mathrm{E}_{1 / 2}=-1.73 \mathrm{~V}$ i.e. $-1.25 \mathrm{~V}$ shift for $\mathrm{Eu}$ ). The substitution of a pyridine arm on TPA by an anionic phenolate arm on BPA ligand renders the metal center significantly more electron-rich and thus more difficult to reduce. As a result the corresponding $\mathrm{Ln}^{2+}$ species are much more reductive.

While the complexes [Yb(TPA) $)_{2} \mathrm{OTf}_{3}$ and $\left[\mathrm{Eu}(\mathrm{TPA})_{2} \mathrm{OTf}_{3}\right.$ did not exhibit any oxidation process in the range $0.5-1 \mathrm{~V}$, the voltammograms of the complex [Yb(BPA) 2$] \mathrm{OTf}$ and [Eu(BPA) ${ }_{2}$ ]OTf show also an irreversible oxidation at $0.70 \mathrm{~V}$ and $0.72 \mathrm{~V}$, respectively attributed to the oxidation of the phenol function on the BPA ligand that are easier to oxidize than the tertiary amine (see supporting info).

A summary of the redox potentials is given in Table 3 to 6 .

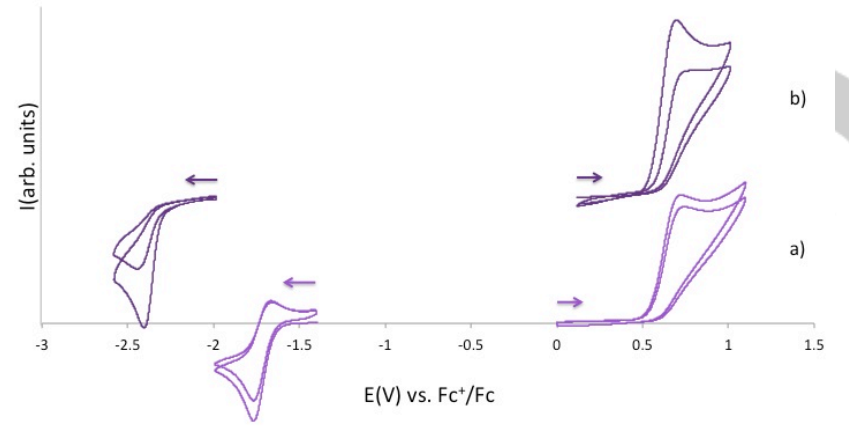

Figure 8. Cyclic voltammogram for $4 \mathrm{mM}$ solutions of a) [Eu(BPA $\left.)_{2}\right] \mathrm{OTf}$ and b) $\left[\mathrm{Yb}(\mathrm{BPA})_{2}\right] \mathrm{OTf}$ in $\sim 0.1 \mathrm{M}\left[\mathrm{Bu}_{4} \mathrm{~N}\right]\left[\mathrm{PF}_{6}\right]$ acetonitrile solution at $100 \mathrm{mV} . \mathrm{s}^{-1}$ scanrate.

In order to assess the effect of electron-donor substituents on the redox properties of the $\left[\mathrm{Yb}(\mathrm{BPA})_{2}\right] \mathrm{OTf} \mathrm{T}_{3}$ and $\left[\mathrm{Eu}(\mathrm{BPA})_{2}\right] \mathrm{OTf}_{3}$ complexes, the redox properties of the complexes of the BPPA ligand containing electron-donor substituents on the phenolate arm were investigated.

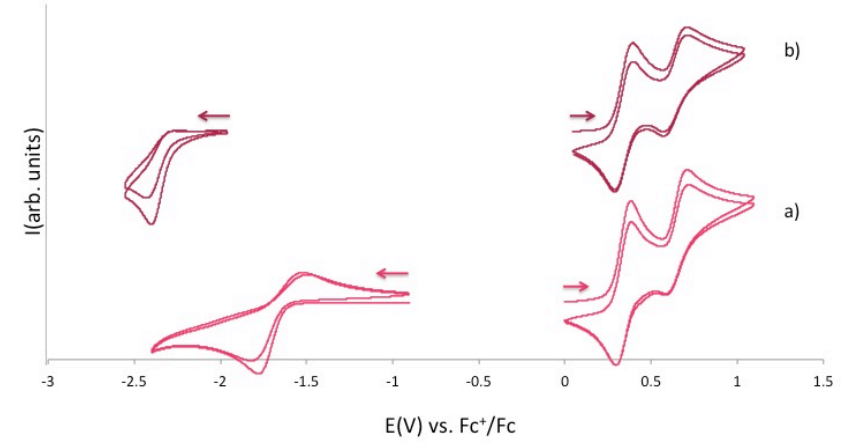

Figure 9. Cyclic voltammogram for $4 \mathrm{mM}$ solutions of a) [Eu(BPPA) $)_{2}$ OTf and b) $\left[\mathrm{Yb}(\mathrm{BPPA})_{2}\right] \mathrm{OTf}$ in $\sim 0.1 \mathrm{M}\left[\mathrm{Bu}_{4} \mathrm{~N}\right]\left[\mathrm{PF}_{6}\right]$ acetonitrile solution at $100 \mathrm{mV} . \mathrm{s}^{-1}$ scan-rate.

The cyclic voltammograms of solutions of the trivalent complexes [Yb(BPPA) $)_{2}$ OTf and [Eu(BPPA) $)_{2}$ OTf in acetonitrile (Figure 9) show that the presence of the tert-butyl groups in meta and para position of the phenolate arm in the BPPA ligand does not affect significantly the reduction potential of the lanthanide ions. Notably, the reduction potentials of both [Yb(BPPA) 2] OTf $\left(E_{p c}=-2.40 \mathrm{~V}\right)$ and [Eu(BPPA)2]OTf $\left(E_{p c}=-1.78\right.$ $\mathrm{V})$ are similar to those of $\left[\mathrm{Yb}(\mathrm{BPA})_{2}\right] \mathrm{OTf}\left(\mathrm{E}_{\mathrm{pc}}=-2.41 \mathrm{~V}\right)$ and [Eu(BPA) $)_{2}$ OTf $\left(E_{p c}=-1.77 \mathrm{~V}\right)$ respectively. This shows that the electron-donor effect of the tert-butyl group is large enough to impact the reduction potential.

Two quasi-reversible oxidation events occur at $E_{1 / 2}=0.34 \mathrm{~V}$ and $0.65 \mathrm{~V}$, which are attributed to the oxidation of the two phenol groups in phenoxyl radicals stabilized by the tert-butyl groups in ortho and para positions. Such stabilization explains the reversibility of this oxidation process compared to the irreversible oxidation of the BPA ligand in the analogous [Yb(BPA)2] OTf and [Eu(BPA)2]OTf complexes.

The cyclic voltammograms obtained in acetonitrile or THF solutions of the trivalent "ate" complexes [Yb(MPA) ${ }_{2} \mathrm{~K}$ ] and $\left[\mathrm{Eu}(\mathrm{MPA})_{2} \mathrm{~K}\right]$ prepared "in situ" do not present any redox event at the metal center (Figure S.C.3). These results suggest that the presence of four phenolate oxygen donors shifts significantly the redox potential towards lower values. The second cycle presents some small reduction wave apparently linked to ligand oxidation processes. The ligand based redox processes are much more difficult to interpret than for the analogous BPPA complexes.

\section{Reactivity}

A preliminary study of the reactivity of the isolated $\mathrm{Ln}^{2+}$ complexes with heteroallens has been carried out. The $\mathrm{Ln}^{2+}$ complexes $\left.\left[\operatorname{Ln}(T P A)_{2}\right]\right]_{2}$ do not react with $\mathrm{CO}_{2}$ or $\mathrm{CS}_{2}$. The $\left[\mathrm{Eu}(\mathrm{BPA})_{2}\right]$ and $\left[\mathrm{Eu}(\mathrm{MPA})_{2} \mathrm{~K}_{2}\right]$ complexes do not react with carbon dioxide. In contrast $\left[\mathrm{Eu}(\mathrm{BPA})_{2}\right]$ reduces $\mathrm{CS}_{2}$. When 1 eq of ${ }^{13} \mathrm{CS}_{2}$ was added to a THF suspension or a pyridine solution of [Eu(BPA $\left.)_{2}\right]$, a color change from purple to red was observed. Only the signals of the trivalent Eu complex $\left[\mathrm{Eu}(\mathrm{BPA})_{2}\right]^{+}$appear in the ${ }^{1} \mathrm{H}$ NMR spectrum probably due to the fluxional nature of a putative $\left[\mathrm{Eu}\left(\mathrm{CS}_{3}\right)(\mathrm{BPA})_{2}\right]^{-}$complex. Dissolution of the reaction mixture in deuterated DMSO leads to the release of the free 
ligand BPA and to the appearance in the proton NMR spectrum of an additional set of paramagnetic signals assigned to the thiocarbonate complex $\left[\mathrm{Eu}(\mathrm{BPA})\left(\mathrm{CS}_{3}\right)(\mathrm{DMSO})_{2}\right]$ (Scheme 5). Slow diffusion of toluene into a DMSO solution of the reaction products lead to the isolation in $33 \%$ yield of the analytically pure $\left[\mathrm{Eu}(\mathrm{BPA})\left(\mathrm{CS}_{3}\right)(\mathrm{DMSO})_{2}\right]$. The structure of the complex was confirmed by $\mathrm{X}$-ray diffraction analysis. When 1 eq of ${ }^{13} \mathrm{CS}_{2}$ is added to a $1: 1$ solution of $\mathrm{Eul}_{2}$ and KBPA in pyridine, the formation of the $\left[\mathrm{Eu}(\mathrm{BPA})_{2}\right]^{+}$complex is observed by proton NMR. However the ${ }^{1} \mathrm{H}$ NMR of the reaction mixture in deuterated DMSO does not show the formation of the $\left[\mathrm{Eu}(\mathrm{BPA})\left(\mathrm{CS}_{3}\right)(\mathrm{DMSO})_{2}\right]$. This suggests that, in this case, different products are formed from the reduction of $\mathrm{CS}_{2}$ that could not be identified.

Scheme 5. Synthesis of $\left[\mathrm{Eu}(\mathrm{BPA})\left(\mathrm{CS}_{3}\right)(\mathrm{DMSO})_{2}\right]$.

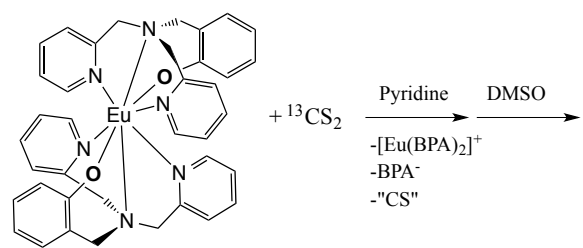

$\left[\mathrm{Eu}(\mathrm{BPA})_{2}\right]$

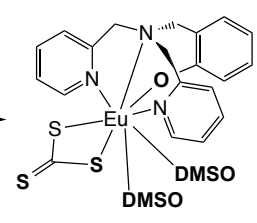

$\left[\mathrm{Eu}(\mathrm{BPA})_{2}\left(\mathrm{CS}_{3}\right)(\mathrm{DMSO})_{2}\right]$
The structure $\left[\mathrm{Eu}(\mathrm{BPA})\left(\mathrm{CS}_{3}\right)(\mathrm{DMSO})_{2}\right]$ (Figure 10) shows the presence a trivalent europium ion surrounded by one BPA ligand and a terminal thiocarbonate moiety. The coordination sphere is completed by two DMSO molecules. The europium center is octacoordinated in a distorted dodecahedral fashion. The values of the Eu- $\mathrm{N}_{\text {amine, }}$ of Eu- $\mathrm{N}_{\text {pyridyl }}$ and Eu-O $\mathrm{O}_{\text {phenol distances }}$ (respectively 2.672(6) $\AA$, 2.601(7) $\AA$ and 2.588(7) $\AA$ and 2.272(5) $\AA$ ) are very similar to those found in the $\mathrm{Eu}^{3+}$ bis-ligand complex [Eu(BPA $)_{2}$ ]OTf. The average Eu-S bond (2.88(1) $\AA$ ) falls in the range of Eu-S distances previously reported for $\mathrm{Eu}^{3+}$ thiocarbamate complexes. ${ }^{[25]}$ The S-C bonds of the thiocarbonate moiety, S1-C2 and S2-C2 measure respectively $1.735(10) \AA$ and $1.725(10) \AA$. The S3 atom is disordered between two positions. The main position (55\% occupancy) leads to a C-S distance of $1.748(15) \AA$, the minor position $(45 \%$ occupancy) leads to a shorter C-S distance of $1.630(16) \AA$. The $\mathrm{C}-\mathrm{S}$ bond distances remain in the range of previously reported trithiocarbonate complexes. , ${ }^{[26-27]}$

There are two previous reports of trithiocarbonate complexes containing $f$ elements, ${ }^{[28-29]}$ but the complex $\left[\mathrm{Eu}(\mathrm{BPA})\left(\mathrm{CS}_{3}\right)\left(\mathrm{DMSO}_{2}\right]\right.$ is the first example of a trithiocarbonate complex containing a $4 \mathrm{f}$ element. Moreover only three examples of $\mathrm{CS}_{2}$ reduction by lanthanide complexes have been reported before. The reduction of $\mathrm{CS}_{2}$ by $\mathrm{Eu}^{2+}$ and $\mathrm{Yb}^{2+}$ tetrasiloxide complexes has been reported by our group ${ }^{[5 c]}$ and was found, by ${ }^{13} \mathrm{C}$ NMR studies, to afford trithiocarbonate and tetrathioxalate products in different ratios depending on the $\mathrm{Ln}^{2+}$ ion. However, the $\mathrm{CS}_{2}$ reduction products are quickly released in the reaction media and no lanthanide bound product was isolated. Very
Table 3. Voltammetric data for Eu complexes (vs Fc+/Fc).

\begin{tabular}{|c|c|c|c|c|}
\hline \multirow{2}{*}{ Compounds } & \multicolumn{2}{|c|}{ Metal-based wave } & \multicolumn{2}{|c|}{ Ligand-based waves } \\
\hline & $E_{p c}(V)$ & $E_{p a}(V)$ & $\mathrm{E}_{\mathrm{pa} 1}(\mathrm{~V})$ & $\mathrm{E}_{\mathrm{pa} 2}(\mathrm{~V})$ \\
\hline$\left[\mathrm{Eu}(\mathrm{TPA})_{2} \mathrm{OOTF}_{3}\right.$ & -0.46 & -0.36 & I & I \\
\hline$\left[\mathrm{Eu}(\mathrm{BPA})_{2}\right]_{\mathrm{OTF}_{3}}$ & -1.77 & -1.66 & 0.72 & I \\
\hline$\left[\mathrm{Eu}(\mathrm{BPPA})_{2}\right]_{\mathrm{OTF}}$ & -1.78 & -1.52 & $E_{1 / 2}=0.34$ & $E_{1 / 2}=0.65$ \\
\hline \multirow{2}{*}{ Compounds } & \multicolumn{2}{|c|}{ Metal-based wave } & \multicolumn{2}{|c|}{ Ligand-based waves } \\
\hline & $E_{p c}(V)$ & $E_{p a}(V)$ & $\mathrm{E}_{\mathrm{pa} 1}(\mathrm{~V})$ & $\mathrm{E}_{\mathrm{pa} 2}(\mathrm{~V})$ \\
\hline$\left[\mathrm{Eu}(\mathrm{TPA})_{2}\right]_{\mathrm{OTF}}$ & 0.17 & 0.27 & I & I \\
\hline$\left[\mathrm{Eu}(\mathrm{BPA})_{2}\right]_{\mathrm{OTF}}$ & -1.14 & -1.03 & 1.35 & l \\
\hline$\left[\mathrm{Eu}(\mathrm{BPPA})_{2}\right]_{\mathrm{OTF}}$ & -1.15 & -0.89 & $E_{1 / 2}=0.97$ & $E_{1 / 2}=1.28$ \\
\hline
\end{tabular}

different results were found for the reaction of formamidinato ${ }^{[6 a]}$ and guanidinate ${ }^{[6 b]}$ complexes of $\mathrm{Sm}^{2+}$ with $\mathrm{CS}_{2}$. These compounds were found to promote a C-S coupling reaction affording the thioformyl carbonotrithioate the $\left(\left(\operatorname{SCSCS}_{2}\right)^{2-}\right)$ bridging ligand.

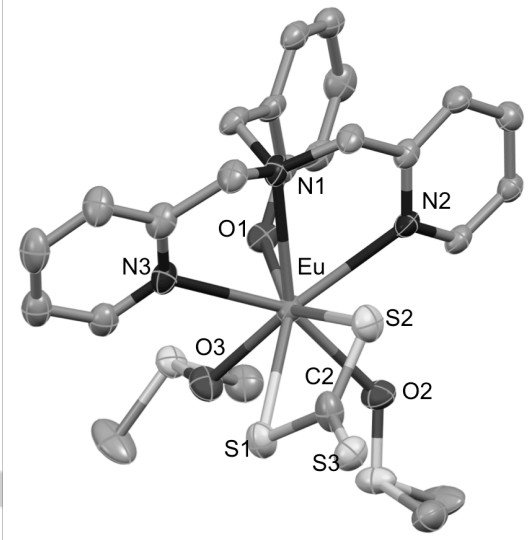

Figure 10. Ellipsoid diagram of $\left[\mathrm{Eu}(\mathrm{BPA})\left(\mathrm{CS}_{3}\right)(\mathrm{DMSO})_{2}\right](50 \%$ probability ellipsoids). Hydrogen atoms, disorder and solvent molecules are omitted for clarity.

Table 5. Voltammetric data for $\mathrm{Yb}$ complexes (vs Fc+/Fc).

\begin{tabular}{cccc}
\hline \multirow{2}{*}{ Compounds } & \multicolumn{2}{c}{ Metal-based wave } & \multicolumn{2}{l}{ Ligand-based waves } \\
\cline { 2 - 4 } & $\mathrm{E}_{\mathrm{pc}}(\mathrm{V})$ & $\mathrm{E}_{\mathrm{pa} 1}(\mathrm{~V})$ & $\mathrm{E}_{\mathrm{pa} 2}(\mathrm{~V})$ \\
\hline
\end{tabular}

$\left[\mathrm{Yb}(\mathrm{TPA})_{2}\right]_{\mathrm{OTF}} \quad-1.17 \quad\left(\mathrm{E}_{1 / 2}=-1.11\right) \quad /$ 
$\left[\mathrm{Yb}(\mathrm{BPA})_{2}\right]_{\mathrm{OTF}}$ $-2.41$

$-2.40$

0.70

/

$\left[\mathrm{Yb}(\mathrm{BPPA})_{2} \mathrm{OTF}_{3}\right.$

$E_{1 / 2}=0.34$

$E_{1 / 2}=0.64$

Table 6. Voltammetric data for Yb complexes (vs NHE).

\begin{tabular}{|c|c|c|c|c|}
\hline \multirow{2}{*}{ Compounds } & \multirow{2}{*}{\multicolumn{2}{|c|}{$\frac{\text { Metal-based wave }}{E_{p c}(V)}$}} & \multicolumn{2}{|c|}{ Ligand-based waves } \\
\hline & & & $\mathrm{E}_{\mathrm{pa} 1}(\mathrm{~V})$ & $\mathrm{E}_{\mathrm{pa} 2}(\mathrm{~V})$ \\
\hline$\left[\mathrm{Yb}(\mathrm{TPA})_{2}\right]_{\mathrm{OTF}}$ & -0.54 & $\left(E_{1 / 2}=-0.48\right)$ & I & 1 \\
\hline$\left[\mathrm{Yb}(\mathrm{BPA})_{2} \mathrm{OTF}_{3}\right.$ & & -1.78 & 1.33 & 1 \\
\hline$\left[\mathrm{Yb}(\mathrm{BPPA})_{2}\right] \mathrm{OTF}_{3}$ & & -1.77 & $E_{1 / 2}=0.97$ & $E_{1 / 2}=1.27$ \\
\hline
\end{tabular}

\section{Conclusions}

Complexation studies have been performed with a series of tetradentate tripodal pyridylamine and pyridylaminephenolate ligands for the lanthanide ions $\mathrm{Eu}$ and $\mathrm{Yb}$ in their oxidation state III and II. Stable mono ligand and bis-ligand complexes of $\mathrm{Eu}^{2+}$ and $\mathrm{Yb}^{2+}$ have been prepared and characterized with the neutral tetradentate ligand TPA. The replacement of one pyridyl group by a phenolate group in the ligand $\mathrm{BPA}^{-}$leads to a decreased stability of the bis-ligand complex of $\mathrm{Yb}^{2+}$ preventing its isolation but the mono-BPA complex of divalent $\mathrm{Yb}$ can be isolated and it is stable in acetonitrile solution. The bis-ligand complexes of $\mathrm{Eu}^{2+}$ and $\mathrm{Eu}^{3+}$ with BPA- were also isolated and their solid state structure was characterized. The neutral $\mathrm{Eu}^{2+}$ complex $\left[\mathrm{Eu}(\mathrm{BPA})_{2}\right]$ is stable in acetonitrile solution. The replacement of two pyridyl groups by two phenolate group in the ligand MPA ${ }^{2-}$ leads to a further decrease of the stability of the bis-ligand complexes of $\mathrm{Eu}^{2+}$ and $\mathrm{Yb}^{2+}$ preventing their isolation. Cyclic voltammetry studies carried out on the bis-ligand complexes of $\mathrm{Eu}^{3+}$ and $\mathrm{Yb}^{3+}$ show that the metal center reduction occurs at significantly lower potentials for the BPA- ligand compared to the TPA ligands. No metal centered redox event was observed in the used conditions for the bis-MPA complexes most likely due to the fact that metal reduction occurs at even lower potential. These studies show that the successive replacement of pyridyl groups by phenolate groups, leading to more electron-rich ligands, results in significant differences in the reducing character of the lanthanide complexes of TPA, BPA and MPA ${ }^{2-}$ ligands. The important differences in the stability and reactivity of the investigated complexes are probably due to the observed difference in redox potential. Preliminary reactivity studies show that, while the bis-TPA complexes of $\mathrm{Eu}^{2+}$ and $\mathrm{Yb}^{2+}$ do not react with heteroallenes, the $\left[\mathrm{Eu}(\mathrm{BPA})_{2}\right]$ complex reduces $\mathrm{CS}_{2}$ affording the first example of a lanthanide trithiocarbonate complex. Future work will be directed to investigate the reactivity of heteroleptic $\mathrm{Ln}^{2+}$ complexes of $\mathrm{BPA}^{-}$and $\mathrm{MPA}^{2-}$ with different substrates.

\section{Experimental Section}

General Considerations. Unless otherwise noted, all manipulations were carried out at ambient temperature under an inert argon atmosphere using Schlenk techniques and an MBraun glovebox equipped with a purifier unit. The water and oxygen levels were always kept at less than $1 \mathrm{ppm}$. Glassware was dried overnight at $130^{\circ} \mathrm{C}$ before use.

${ }^{1} \mathrm{H}$ NMR experiments were carried out using NMR tubes adapted with $\mathrm{J}$. Young valves. ${ }^{1} \mathrm{H}$ NMR spectra were recorded on Bruker $200 \mathrm{MHz}$ and $400 \mathrm{MHz}$ spectrometers. NMR chemical shifts are reported in ppm with solvent as internal reference.

Elemental analyses were performed under argon by Analytische Laboratorien GMBH at Lindlar, Germany.

Starting materials. Unless otherwise noted, reagents were purchased from commercial suppliers and used without further purification. The solvents were purchased from Aldrich or Eurisotop (deuterated solvents) in their anhydrous form, conditioned under argon and vacuum distilled from K/benzophenone (hexane, Pyridine, DIPE, dme and THF). Acetonitrile was let 2 days at reflux on $\mathrm{CaH}_{2}$ prior to be distilled. All reagents were dried under high-vacuum for 7 days prior to use. TPA was purchased from Aldrich and recrystallize from $\mathrm{Et}_{2} \mathrm{O}$ prior to use. 2-(3,5-Ditert-butyl-2-hydroxybenzylaminomethyl)pyridine was prepared according to the published procedure. ${ }^{[28]}$

The ligand HBPPA ${ }^{[29]}$ was prepared according to the published procedure. The previously reported HBPA ligand ${ }^{[30]}$ was prepared in $78 \%$ yield with the same procedure ${ }^{[29]}$ used for ligand HBPPA. The previously reported ligand $\mathrm{H}_{2} \mathrm{MPA}^{[21]}$ was synthetized from 2-(3,5-Di-tert-butyl-2hydroxybenzylaminomethyl)pyridine in $24 \%$ yield according to the literature procedure used for a similar system. ${ }^{[28]}$ The proton NMR data are in agreement with those reported in the literature. The potassium salts of all ligands were prepared according to a published procedure. ${ }^{[13 b]}$ The complexes $\left[\mathrm{Ln}(\mathrm{TPA})_{2} \mathrm{OTf}_{3}(\mathrm{Ln}=\mathrm{Eu}\right.$ and $\mathrm{Yb})$ were prepared "in situ" according to the published procedure. ${ }^{[15 a]}$

\section{KBPA.}

${ }^{1} \mathrm{H}$ NMR (200 MHz, py-d $\left.\mathrm{d}_{5}, 298 \mathrm{~K}\right): \delta=8.3(\mathrm{~d}, 2 \mathrm{H}), 7.5-7.1(\mathrm{~m}, 7 \mathrm{H}), 6.9$ (dd, 2H), $6.5(\mathrm{td}, 1 \mathrm{H}), 3.7(\mathrm{~m}, 6 \mathrm{H})$.

\section{KBPPA.}

HBPPA (1.1 g, $2.5 \mathrm{mmol}, 1$ equiv) and potassium hydride $(0.11 \mathrm{~g}, 2.8$ $\mathrm{mmol}, 1.1$ equiv) were mixed in anhydrous THF $(25 \mathrm{~mL})$. The reaction mixture was put at reflux under argon for 12 hours. The mixture was then filtered to remove the excess of $\mathrm{KH}$, the filtrate was taken to dryness and washed with $10 \mathrm{~mL}$ of hexane. The obtained solid was dried under vacuum for 2 days to give KBPPA(THF) $0.65(0.9 \mathrm{~g}, 1.7 \mathrm{mmol}, 68 \%$ yield) where the amount of THF was determined by quantitative ${ }^{1} \mathrm{H}$ NMR. ${ }^{1} \mathrm{H}$ NMR $\left(200 \mathrm{MHz}, \mathrm{py}-\mathrm{d}_{5}, 298 \mathrm{~K}\right): \delta=8.3(\mathrm{~d}, 2 \mathrm{H}), 7.5-7.2(\mathrm{~m}, 6 \mathrm{H}), 6.9(\mathrm{dd}$, $2 \mathrm{H}), 3.9(\mathrm{~s}, 2 \mathrm{H}), 3.8(\mathrm{~s}, 4 \mathrm{H}), 1.8(\mathrm{~s}, 9 \mathrm{H}), 1.5(\mathrm{~s}, 9 \mathrm{H})$.

\section{K2MPA.}

${ }^{1} \mathrm{H}$ NMR. ${ }^{1} \mathrm{H}$ NMR $(200 \mathrm{MHz}$, py-d $5,298 \mathrm{~K}): \delta=7.9(\mathrm{~d}, 1 \mathrm{H}), 7.4-7.3(\mathrm{~m}$, $4 \mathrm{H}), 7.1(\mathrm{~d}, 2 \mathrm{H}), 6.7(\mathrm{t}, 1 \mathrm{H}), 4.1(\mathrm{~s}, 2 \mathrm{H}), 3.9(\mathrm{bs}, 4 \mathrm{H}), 1.7(\mathrm{~s}, 18 \mathrm{H}), 1.4(\mathrm{~s}$, $18 \mathrm{H})$ 


\section{Synthesis of [Ln(TPA)I2] $(\mathrm{Ln}=\mathrm{Eu}, \mathrm{Yb}, \mathrm{Sm})$.}

Ln=Eu, Sm. Addition of a solution of TPA (20.9 mg, $0.071 \mathrm{mmol})$ in THF (1 $\mathrm{mL})$ to a stirred solution of $\mathrm{Lnl}_{2}$ (1 equiv) in THF $(1 \mathrm{~mL})$ resulted in an orange suspension for $\left[E u(T P A) I_{2}\right]$ and a red-purple suspension for $\left[\mathrm{Sm}(\mathrm{TPA}) \mathrm{I}_{2}\right]$. After filtration, the residue was washed several times with THF and hexane and dried under vacuum to yield [Eu(TPA) $\left.\right|_{2}$ ] as an orange powder in $90 \%$ yield and $\left[\mathrm{Sm}(\mathrm{TPA}) \mathrm{I}_{2}\right.$ ] as a red-purple powder in $82 \%$ yield. Crystals suitable for X-ray diffraction were obtained for $L n=E u$ by slow diffusion of DIPE into an acetonitrile solution of the complex. Anal. Calcd for $\left[\mathrm{Eu}(\mathrm{TPA}) \mathrm{I}_{2}\right]\left(\mathrm{C}_{36} \mathrm{H}_{36} \mathrm{I}_{4} \mathrm{~N}_{8} \mathrm{Eu}_{2}\right) \mathrm{C} 31.06, \mathrm{H} 2.61, \mathrm{~N} 8.05$ found $\mathrm{C} \quad 31.11, \mathrm{H} \quad 2.75, \mathrm{~N}$ 8.18. For $\left[\mathrm{Sm}(\mathrm{TPA}) \mathrm{I}_{2}(\mathrm{THF})_{0.2}\right.$ ] $\left(\mathrm{C}_{18.8} \mathrm{H}_{19.6} \mathrm{I}_{2} \mathrm{~N}_{8} \mathrm{O}_{0.2} \mathrm{Sm}\right) \mathrm{C} 31.85, \mathrm{H} 2.79, \mathrm{~N} 7.90$; found C 31.84, H 3.4, N 7.96 .

$\mathbf{L n}=\mathbf{Y b}$. Slow addition of a solution of TPA $(11.3 \mathrm{mg}, 0.039 \mathrm{mmol})$ in $\mathrm{CH}_{3} \mathrm{CN}\left(2 \mathrm{~mL}\right.$ ) to a stirred orange solution of $\mathrm{Ybl}_{2}$ (1 equiv) in $\mathrm{CH}_{3} \mathrm{CN}$ (2 $\mathrm{mL}$ ) resulted in a dark blue solution. After stirring for $3 \mathrm{~h}$, the reaction mixture was layered with DIPE. Big dark crystals formed in 3 days and were collected by filtration and dried under vacuum to yield $\left[\mathrm{Yb}(\mathrm{TPA}) \mathrm{I}_{2}\left(\mathrm{CH}_{3} \mathrm{CN}\right)_{0.6}\right]$ in $69 \%$ yield. Crystals suitable for $\mathrm{X}$-ray diffraction were obtained by slow diffusion of DIPE into a $\mathrm{CH}_{3} \mathrm{CN}$ solution of the complex. ${ }^{1} \mathrm{H}$ NMR $\left(200 \mathrm{MHz}, \mathrm{CD}_{3} \mathrm{CN}, 298 \mathrm{~K}\right): \delta=8.8(\mathrm{~s}, 3 \mathrm{H}), 7.8(\mathrm{t}, 3 \mathrm{H})$ $7.3(\mathrm{~d}, 6 \mathrm{H}), 4.0(\mathrm{~s}, 6 \mathrm{H})$. Anal. Calcd for $\left[\mathrm{Yb}(\mathrm{TPA}) \mathrm{I}_{2}\left(\mathrm{CH}_{3} \mathrm{CN}\right)_{0.6}\right]$ $\left(\mathrm{C}_{19.2} \mathrm{H}_{19.8} \mathrm{l}_{2} \mathrm{~N}_{4.6} \mathrm{Yb}\right) \mathrm{C} 31.09, \mathrm{H} 2.69, \mathrm{~N} 8.69$; found $\mathrm{C} 30.86, \mathrm{H} 2.80, \mathrm{~N}$ 8.84 .

\section{Synthesis of the complexes $\left[\operatorname{Ln}(T P A)_{2}\right] l_{2}(\operatorname{Ln}=\mathrm{Eu}, \mathrm{Yb}, \mathrm{Sm})$.}

Addition of TPA (20 mg, $0.068 \mathrm{mmol}, 2$ equiv) in THF (2 mL) to a stirring solution of $\mathrm{Lnl}_{2}$ (1 equiv) in THF (2 mL) resulted in a color change (to dark red for $L n=E u$, to green for $L n=Y b$ and to purple-violet for $L n=S m$ ). A solid precipitates out of the solution after few minutes. After filtration, the solids were washed several times with THF and hexane and dried under vacuum to yield $\left[\mathrm{Ln}(\mathrm{TPA})_{2}\right] \mathrm{l}_{2}$ as powder in $76 \%$ yield. Crystals suitable for $X$-ray diffraction were obtained by slow diffusion of a solution of TPA in THF into a solution of $\mathrm{Lnl}_{2}$ in THF (for $\mathrm{Ln}=\mathrm{Eu}$ and $\mathrm{Sm}$ ) and from slow diffusion of DIPE into an acetonitrile solution of $\left[\mathrm{Yb}(\mathrm{TPA})_{2}\right] \mathrm{I}_{2} .{ }^{1} \mathrm{H} \mathrm{NMR}$ $\left(200 \mathrm{MHz}, \mathrm{CD}_{3} \mathrm{CN}, 298 \mathrm{~K}\right.$ ): For $\mathrm{Ln}=\mathrm{Yb}: \delta=7.9(\mathrm{~s}, 6 \mathrm{H}), 7.5(\mathrm{~d}, 6 \mathrm{H}), 7.4(\mathrm{~s}$ $6 \mathrm{H}), 6.9(\mathrm{~s}, 6 \mathrm{H}), 4.2(\mathrm{~s}, 12 \mathrm{H})$. For $\mathrm{Ln}=\mathrm{Sm}: \delta=23.8(\mathrm{~s}, 6 \mathrm{H}), 11.5(\mathrm{~d}, 6 \mathrm{H})$ 4.6-4.2 $(\mathrm{m}, 6 \mathrm{H}), 3.9-3.6(\mathrm{~m}, 6 \mathrm{H}),-12.2(\mathrm{~s}, 12 \mathrm{H})$. Anal. Calcd for $\left[\mathrm{Eu}(\mathrm{TPA})_{2}\right] \mathrm{l}_{2}\left(\mathrm{C}_{36} \mathrm{H}_{36} \mathrm{l}_{2} \mathrm{~N}_{8} \mathrm{Eu}\right): \mathrm{C} 43.83, \mathrm{H} 3.68, \mathrm{~N}$ 11.36; found $\mathrm{C} 43.53, \mathrm{H}$ 3.85, N 11.44. For [Yb(TPA) $\left.{ }_{2}\right] l_{2}\left(\mathrm{C}_{36} \mathrm{H}_{36} \mathrm{l}_{2} \mathrm{~N}_{8} \mathrm{Yb}\right)$ : C 42.92, H 3.60, N 11.12; found $\mathrm{C} 42.54, \mathrm{H} 3.70, \mathrm{~N}$ 11.26. For [Sm(TPA) $)_{2} \mathrm{l}_{2}\left(\mathrm{C}_{36} \mathrm{H}_{36} \mathrm{l}_{2} \mathrm{~N}_{8} \mathrm{Sm}\right)$ : C 43.90, H 3.68, N 11.38; found C 43.75, H 3.81, N 11.41

\section{Synthesis of $\left[\mathrm{Eu}(\mathrm{BPA})_{2}\right] \mathrm{OTf}$}

A white suspension of KBPA (118.2 $\mathrm{mg}, 0.34 \mathrm{mmol}, 2$ equiv) in THF $(2 \mathrm{~mL})$ was added to a white suspension of $\mathrm{Eu}(\mathrm{OTf})_{3}(103.2 \mathrm{mg}, 0.17$ $\mathrm{mmol}, 1$ equiv) in THF $(2 \mathrm{~mL})$ and stirred $30 \mathrm{~min}$. The reaction mixture turned yellow in few seconds and a white precipitate formed (KOTf) that was filtered out. The resulting solution was layered with DIPE. Orange crystals formed in 2 days and they were filtered and dried under vacuum for $24 \mathrm{~h}$ leading to $151.3 \mathrm{mg}$ of [Eu(BPA)2]OTf.(KOTf) 0.1 (0.16 mmol, $95 \%$ yield). Orange crystals suitable for $\mathrm{X}$-ray diffraction were obtained by slow diffusion of DIPE into a THF solution of the complex. ${ }^{1} \mathrm{H}$ NMR (200 $\left.\mathrm{MHz}, \mathrm{py}-\mathrm{d}_{5}, 298 \mathrm{~K}\right) \delta=30.6(\mathrm{bs}, 4 \mathrm{H}), 13.0-11.8(\mathrm{bm}, 12 \mathrm{H}), 2.0-1.0(\mathrm{bm}$ $6 \mathrm{H}),-2.5$ to $-4.0(\mathrm{bm}, 8 \mathrm{H}),-15.7$ (bs, $4 \mathrm{H}),-18.2(\mathrm{bs}, 2 \mathrm{H})$. Anal. Calcd for [Eu(BPA) $)_{\mathrm{OTf}}(\mathrm{KOTf})_{0.1}\left(\mathrm{C}_{39.1} \mathrm{H}_{36} \mathrm{~N}_{6} \mathrm{O}_{5.3} \mathrm{~F}_{3.3} \mathrm{~S}_{1.1} \mathrm{~K}_{0.1} \mathrm{Eu}\right) \mathrm{C} 50.57, \mathrm{H} 3.91, \mathrm{~N}$ 9.05; found C $50.62, \mathrm{H} 3.88, \mathrm{~N} 9.14$

Synthesis of [Eu(BPA) 2$]$
A solution of $\mathrm{Eul}_{2}(200.0 \mathrm{mg}, 0.49 \mathrm{mmol}, 1$ equiv) in THF ( $3 \mathrm{~mL}$ ) was added to a white suspension of KBPA (338.2 $\mathrm{mg}, 0.98 \mathrm{mmol}, 2$ equiv) in THF $(6 \mathrm{~mL})$ affording a red-brown suspension. After $1 \mathrm{~h}$ of stirring, the mixture was filtered. The brown solid obtained was extracted in pyridine $(4 \mathrm{~mL})$ to remove $\mathrm{KI}$. The two filtrates were combined, concentrated and layered with hexane. After 1 week brown crystals formed, they were collected, washed with hexane and dried under vacuum for $24 \mathrm{~h}$ to yield $318 \mathrm{mg}$ of $\left[\mathrm{Eu}(\mathrm{BPA})_{2}\right](0.42 \mathrm{mmol}, 85 \%$ yield $)$. Dark brown crystals suitable for X-ray diffraction were obtained by slow diffusion of hexane into a pyridine solution of the complex. Anal. Calcd for $\left[\mathrm{Eu}(\mathrm{BPA})_{2}\right]$ $\left(\mathrm{C}_{38} \mathrm{H}_{36} \mathrm{~N}_{6} \mathrm{O}_{2} \mathrm{Eu}\right) \mathrm{C} 60.00, \mathrm{H} 4.77, \mathrm{~N} 11.05$; found $\mathrm{C} 59.61, \mathrm{H} 4.74, \mathrm{~N}$ 10.95 .

\section{Synthesis of [Yb(BPA)I]}

A white suspension of $\mathrm{KBPA}(0.051 \mathrm{mmol}, 1 \mathrm{eq})$ in $\mathrm{CH}_{3} \mathrm{CN}(1.5 \mathrm{~mL})$ was added drop by drop to an orange solution of $\mathrm{Ybl}_{2}(\mathrm{THF})_{2.1}(0.051 \mathrm{mmol}$, 1eq) in $\mathrm{CH}_{3} \mathrm{CN}(1.5 \mathrm{~mL})$ and stirred $18 \mathrm{~h}$. The resulting mixture turned dark green in few seconds. The mixture was then concentrated to $2 \mathrm{~mL}$ and filtered. The filtrate was layered with DIPE. A dark green cristallin solid formed after 24 hours. The proton NMR spectrum shows the presence of only one set of signals assigned to the $\left[\mathrm{Yb}(\mathrm{BPA}) \mathrm{I}\left(\mathrm{CH}_{3} \mathrm{CN}\right)\right]_{2}$ complex. Unfortunately the obtention of a satisfactory elemental analysis was prevented by the co-crystallization of $\mathrm{KI}$ that we were no able to separate. X-ray quality dark green crystals of $\left[\mathrm{Yb}(\mathrm{BPA}) \mathrm{I}\left(\mathrm{CH}_{3} \mathrm{CN}\right)\right]_{2} \cdot\left(\mathrm{CH}_{3} \mathrm{CN}\right)_{0.4}$ were obtained from a saturated solution of the complex in $\mathrm{CH}_{3} \mathrm{CN}(24.3 \mathrm{mM}) .{ }^{1} \mathrm{H}$ NMR $\left(400 \mathrm{MHz}, \mathrm{CD}_{3} \mathrm{CN}, 298 \mathrm{~K}\right.$ ) $\delta=8.40(\mathrm{~d}, 2 \mathrm{H}), 7.79(\mathrm{t}, 2 \mathrm{H}), 7.31(\mathrm{~d}, 2 \mathrm{H}), 7.17(\mathrm{~d}, 1 \mathrm{H}), 7.13-7.00(\mathrm{~m}$, $3 \mathrm{H}), 6.84(\mathrm{~d}, 1 \mathrm{H}), 6.53(\mathrm{t}, 1 \mathrm{H}), 3.95-3.69(\mathrm{~m}, 6 \mathrm{H})$.

\section{Synthesis of [Eu(BPPA) 2 ]OTf.}

A white suspension of KBPPA(THF) 0.65 ( $93.3 \mathrm{mg}, 0.18 \mathrm{mmol}, 2$ equiv) in THF (2mL) was added to a white suspension of Eu(OTf)3 (55.6 mg, 0.09 mmol, 1 equiv) in THF $(2 \mathrm{~mL})$ and stirred for $1 \mathrm{~h}$. The resulting suspension turned orange in few seconds. The solvent was then removed under vacuum and pyridine $(2 \mathrm{~mL})$ was added to afford a deep orange suspension that was filtered to partially remove KOTf. Complete removal of KOTf salt is not possible due to the very similar solubility of the desired complex and KOTf. The filtrate was layered with hexane to yield $96.1 \mathrm{mg}$ of [Eu(BPPA) 2 OTf.[KOTf $]_{1.5}(52 \%$ yield) as an orange solid. $\mathrm{X}$-ray quality orange crystals of [Eu(BPPA) 2 ] OTf were obtained by slow diffusion of hexane into a pyridine solution of the complex. ${ }^{1} \mathrm{H}$ NMR (200 $\mathrm{MHz}$, py-d5, $298 \mathrm{~K}$ ) $\delta=30.0$ to -24.0 (broad signals $32 \mathrm{H}), 4.86(\mathrm{~s}, 18 \mathrm{H})$, 15.22 (s, 18H). Anal. Calcd for [Eu(BPPA) 2] ]OTf.[KOTf] 1.5 ( $\left.\mathrm{C}_{56.5} \mathrm{H}_{68} \mathrm{~N}_{6} \mathrm{O}_{9.5} \mathrm{~F}_{7.5} \mathrm{~S}_{2.5} \mathrm{~K}_{1.5} \mathrm{Eu}\right) \mathrm{C} 47.91, \mathrm{H} \mathrm{4.84}$, N 5.93; found C $47.85, \mathrm{H}$ $4.86, \mathrm{~N} 6.21$

\section{Synthesis of [Yb(MPA) $\left.{ }_{2} \mathrm{~K}\right]$.}

A light yellow solution of $\mathrm{K}_{2}$ MPA ( $54.9 \mathrm{mg}, 0.08 \mathrm{mmol}, 2$ equiv) in THF ( 3 $\mathrm{mL}$ ) was added to a suspension of $\mathrm{Yb}(\mathrm{OTf})_{3}(24.8 \mathrm{mg}, 0.04 \mathrm{mmol}, 1$ equiv) in THF (2 $\mathrm{mL})$ affording a pale yellow suspension which was stirred for $4 \mathrm{~h}$. The reaction mixture was evaporated and the resulting solid was extracted with hexane. The insoluble KOTf was removed and the colorless filtrate was concentrated and let standing at $-40^{\circ} \mathrm{C}$. After 15 $\mathrm{h}$, colorless crystals formed that were washed with cold hexane and dried under vacuum for $24 \mathrm{~h}$ to afford $42.5 \mathrm{mg}$ of [Yb(MPA) $\left.{ }_{2} \mathrm{~K}\right][\mathrm{KOTf}]_{0.3}$ (0.03 $\mathrm{mmol}, 78 \%$ yield). Colorless crystals suitable for $\mathrm{X}$-ray diffraction were obtained from a concentrated solution of the complex in $30: 1$ Hexane/dme. ${ }^{1} \mathrm{H}$ NMR (200 MHz, $\left.\mathrm{CD}_{3} \mathrm{CN}, 298 \mathrm{~K}\right) \delta=187.0-148.0(\mathrm{bm}$, 8H), 52.9 (bm, 4H), 43.3 (bs, 2H), 42.4 (bs, 2H), 27.7 (s, 2H), 26.4 (s, $2 \mathrm{H}), 6.2(\mathrm{~s}, 18 \mathrm{H}), 4.8(\mathrm{~s}, 18 \mathrm{H}), 1.6(\mathrm{~s}, 4 \mathrm{H}),-7.6$ (bs, $2 \mathrm{H}),-10.8$ (bs, $2 \mathrm{H})$, - 
43.9 (bs, 18H), -50.9 (bs, 18H). Anal. Calcd for $\left[\mathrm{Yb}(\mathrm{MPA})_{2} \mathrm{~K}\right][\mathrm{KOTf}]_{03}$ $\left(\mathrm{C}_{72.3} \mathrm{H}_{100} \mathrm{~N}_{4} \mathrm{O}_{4.9} \mathrm{~F}_{0.9} \mathrm{~S}_{0.3} \mathrm{~K}_{1.3} \mathrm{Yb}\right) \mathrm{C} 64.13, \mathrm{H} 7.44, \mathrm{~N} 4.14$; found $\mathrm{C} 64.26, \mathrm{H}$ 7.37, N 4.15.

\section{Reaction of $\mathrm{Ybl}_{2}(\mathrm{THF})_{2.4}$ with two equivalents of $\mathrm{K}_{2} \mathrm{MPA}$}

A light yellow solution of $\mathrm{Ybl}_{2}(\mathrm{THF})_{2.4}$ in $\mathrm{THF}-\mathrm{d}_{8}$ and a white suspension of 2 eq of $\mathrm{K}_{2} \mathrm{MPA}$ in THF-d 8 were prepared separately and cooled down to $-40^{\circ} \mathrm{C}$. The cold ligand solution was added to the cold suspension of ytterbium iodide leading to a light orange suspension. The ${ }^{1} \mathrm{H}$ NMR spectrum of this reaction mixture show only the presence of the signals assigned to the trivalent $\mathrm{Yb}$ complex [ $\left.\mathrm{Yb}(\mathrm{MPA})_{2} \mathrm{~K}\right]$.

\section{Synthesis of $\left[\mathrm{Eu}(\mathrm{BPA})\left(\mathrm{CS}_{3}\right)\left(\mathrm{DMSO}_{2}\right]\right.$.}

To a pyridine solution of [Eu(BPA) 2 ] $(0.081 \mathrm{mmol}, 1 \mathrm{eq}), 4.9 \mu \mathrm{L}$ of ${ }^{13} \mathrm{CS}_{2}$ were added. The solution turned from red-brown to red. Then pyridine was removed under vacuum and DMSO was added. Red crystals suitable for X-ray diffraction were obtained from a DMSO solution of the reaction mixture layered with toluene. $11 \mathrm{mg}$ of $\left[\mathrm{EuBPA}\left(\mathrm{CS}_{3}\right)(\mathrm{DMSO})_{2}\right](\mathrm{DMSO})_{0.3}$ were recovered (33\%). Anal. Calcd for [Eu(BPA) $\left.\left(\mathrm{CS}_{3}\right)(\mathrm{DMSO})_{2}\right](\mathrm{DMSO})_{0.3}\left(\mathrm{C}_{26.6} \mathrm{H}_{37.8} \mathrm{~N}_{3} \mathrm{O}_{4.3} \mathrm{~S}_{6.3} \mathrm{Eu}\right)$ C 38.85, H 4.63, N 5.11; found C 38.46, H 4.48, N 4.91.

Electrochemical Methods. Cyclic voltammetry data were carried out at room temperature in an argon-filled glovebox described above. Data were collected using a Biologic SP-300 potentiostat connected to a personal computer. All samples were $4 \mathrm{mM}$ in complex with $0.1 \mathrm{M}$ $\left[\mathrm{Bu}_{4} \mathrm{~N}\right]\left[\mathrm{PF}_{6}\right]$ supporting electrolyte in $\mathrm{CH}_{3} \mathrm{CN}$ solution. The experiments were carried out with a platinum disk $(\mathrm{d}=1 \mathrm{~mm})$ working electrode, a platinum wire counter electrode and an $\mathrm{Ag} / \mathrm{AgCl}$ reference electrode. Potential calibration was performed at the end of each data collection cycle using the ferrocene/ferrocenium $\left[\left(\mathrm{C}_{5} \mathrm{H}_{5}\right)_{2} \mathrm{Fe}\right]^{+/ 0}$ couple as an internal standard $\left(E^{\circ}=0,630 \mathrm{~V} / \mathrm{NHE}\right)$.

Solution of the trivalent complexes $\left[\operatorname{Ln}(T P A)_{2}\right] \mathrm{OTf}_{3} ;\left[\operatorname{Ln}(\mathrm{BPA})_{2}\right] \mathrm{OTf}$ [Ln(BPPA $)_{2}$ ]OTf and [Ln(MPA) $\left.{ }_{2} \mathrm{~K}\right] \quad(\mathrm{Ln}=\mathrm{Eu}$ and $\mathrm{Yb})$ for voltammetric studies were prepared in situ by the addition of 2 equivalents of ligand to the corresponding $\mathrm{LnOTf}_{3}$ salt.

X-ray Crystallography. Diffraction data were taken using an OxfordDiffraction XCallibur S kappa geometry diffractometer (Mo-Ka radiation, graphite monochromator, $\lambda=0.71073 \AA$ ). To prevent evaporation of cocrystallised solvent molecules the crystals were coated with light hydrocarbon oil and the data were collected at $150 \mathrm{~K}$. The cell parameters were obtained with intensities detected on three batches of 5 frames. The crystal-detector distance was $4.5 \mathrm{~cm}$. The number of settings and frames has been established taking in consideration the Laue symmetry of the cell by CrysAlisPro Oxford-diffraction software. ${ }^{[31]}$ Unique intensities detected on all frames using the Oxford-diffraction Red program were used to refine the values of the cell parameters. The substantial redundancy in data allows empirical absorption corrections to be applied using multiple measurements of equivalent reflections with the ABSPACK Oxford-diffraction program. ${ }^{[31]}$ For, [Sm(TPA) $\left.{ }_{2}\right]_{2}$, $[\mathrm{Eu}(\mathrm{TPA}) \mathrm{I}(\mu \mathrm{l})]_{2}, \quad\left[\mathrm{Yb}(\mathrm{TPA})_{2}\right]_{2} \cdot\left(\mathrm{CH}_{3} \mathrm{CN}\right)_{3}, \quad\left[\mathrm{Sm}(\mathrm{TPA})_{2}\right] \mathrm{I}_{3}$, $\left.\mathrm{Yb}(\mathrm{TPA}) \mathrm{I}_{2} \mathrm{CH}_{3} \mathrm{CN}\right] .\left(\mathrm{CH}_{3} \mathrm{CN}\right)_{0.5}$, [Eu(TPA) $)_{2} \mathrm{l}_{2}$, [Eu(BPA) $)_{2}$ ]OTf, [Eu(BPA) $)_{2}$. For $\left[\mathrm{Eu}(\mathrm{BPPA})_{2}\right] \mathrm{OTf} . \mathrm{Py}_{2.5}, \quad\left[\mathrm{Yb}(\mathrm{MPA})_{2} \mathrm{~K}(\mathrm{dme})_{2}\right]$ determination of the crystal shape allowed an analytical absorption correction with ABSPACK Oxford-diffraction. ${ }^{[31]}$ Space groups were determined from systematic absences, and they were confirmed by the successful solution of the structure. The structures were solved by direct methods using the SHELXTL 6.14 package for $\left[S m(T P A)_{2}\right] l_{2}$, $[E u(T P A) I(\mu l)]_{2}$, $\left[\mathrm{Yb}(\mathrm{TPA})_{2}\right]_{2}$. $\left.\left(\mathrm{CH}_{3} \mathrm{CN}\right)_{3}, \quad, \quad \mathrm{Yb}(\mathrm{TPA}) \mathrm{I}_{2} \mathrm{CH}_{3} \mathrm{CN}\right] .\left(\mathrm{CH}_{3} \mathrm{CN}\right)_{0.5}, \quad\left[\mathrm{Eu}(\mathrm{TPA})_{2}\right] \mathrm{I}_{2}$,
[Eu(BPA $\left.)_{2}\right] \mathrm{OTf}$, and by charge flipping method using Superflip ${ }^{[32]}$ for $\left.\left[\mathrm{Sm}(\mathrm{TPA})_{2}\right]\right]_{3}$, [Eu(BPPA $\left.)_{2}\right] \mathrm{OTf} . \mathrm{Py}_{2.5}$, and $\left[\mathrm{Yb}(\mathrm{MPA})_{2} \mathrm{~K}(\mathrm{dme})_{2}\right]$. All nonhydrogen atoms were found by difference Fourier syntheses and refined on $\mathrm{F}^{2}$. For $\left.\left[\mathrm{Sm}(\mathrm{TPA})_{2}\right] \mathrm{l}_{2},\left[\mathrm{Sm}(\mathrm{TPA})_{2}\right]\right]_{3}, \quad\left[\mathrm{Yb}(\mathrm{TPA})_{2}\right] \mathrm{l}_{2} \cdot\left(\mathrm{CH}_{3} \mathrm{CN}\right)_{3}$, , $\left.\mathrm{Yb}(\mathrm{TPA}) \mathrm{I}_{2} \mathrm{CH}_{3} \mathrm{CN}\right] .\left(\mathrm{CH}_{3} \mathrm{CN}\right)_{0.5}, \quad, \quad\left[\mathrm{Eu}(\mathrm{BPPA})_{2}\right] \mathrm{OTf} . \mathrm{Py}_{2.5}, \quad$ and $\left[\mathrm{Yb}(\mathrm{MPA})_{2} \mathrm{~K}(\mathrm{dme})_{2}\right]$ hydrogen atoms were fixed in ideal position and refined with a riding model. All hydrogen atoms were found by Fourier synthesis and isotropically refined for $\left.\left[\operatorname{Eu}(T P A)_{2}\right]\right|_{2}$, $[\operatorname{Eu}(T P A) I(\mu l)]_{2}$, $\left[\mathrm{Eu}(\mathrm{BPA})_{2}\right]$, and $\left[\mathrm{Eu}(\mathrm{BPA})_{2}\right] \mathrm{OTf}$. For [Eu(BPPA) $\left.)_{2}\right] \mathrm{OTf} . \mathrm{Py}_{2.5}$ data reduction were driven taking in account a twin law with two components $(62 \%$ and $38 \%$ ) and the structure was solved with the concatenated hklf5 file. For $\left[\mathrm{Yb}(\mathrm{MPA})_{2} \mathrm{~K}(\mathrm{dme})_{2}\right]$, a squeeze treatment were applied, modeling an electron number corresponding with a dme molecule. For the $\left[\mathrm{Eu}(\mathrm{BPA})\left(\mathrm{CS}_{3}\right)\left(\mathrm{DMSO}_{2}\right](\mathrm{DMSO})\right.$ structure, the diffraction data were measured at low temperature $[100(2) \mathrm{K}]$ using Mo radiation on a Bruker APEX II CCD diffractometer equipped with a kappa geometry goniometer. The data sets were reduced by EvalCCD ${ }^{[33]}$ and then corrected for absorption. ${ }^{[34]}$ The solution and refinement was performed by SHELX.[35] The crystal structure was refined using full-matrix leastsquares based on $\mathrm{F}^{2}$ with all non hydrogen atoms anisotropically defined. Hydrogen atoms were placed in calculated positions by means of the "riding" model. Additional electron density found in the difference Fourier map (due to highly disordered solvent) was treated by the SQUEEZE algorithm of PLATON. ${ }^{[36]}$ Anion $\mathrm{CS}_{3}{ }^{2-}$ and DSMO molecules (bound and free) showed high disorder and were treated by means of the split model and by applying some restraints to their thermal parameters (SIMU card). A tough constraint was applied to the adp's of C22A and C22B (EADP card).

Experimental details for X-ray data collections of all complexes are given in Table S.B.1. Crystallographic data have been deposited for the 12 structures with the Cambridge Crystallographic Data Centre as supplementary publication no. CCDC 1402199-1402209 and CCDC 1404893. These data can be obtained free of charge from CCDC via www.ccdc.cam.ac.uk/data_request/cif.

\section{Acknowledgements}

We thank L. Plassais for technical support and ligand synthesis, and C. Camp for useful discussions. We acknowledge support from the Swiss National Science Foundation and from the Ecole Polytechnique Fédérale de Lausanne (EPFL).

Keywords: ytterbium - europium - heteroallenes reduction • divalent lanthanides $\cdot \mathrm{N}$-donor ligands

[1] a) H. B. Kagan, J. L. Namy, Tetrahedron 1986, 42, 6573-6614; b) G. A. Molander, Chem. Rev. 1992, 92, 29; c) W. J. Evans, Coord. Chem. Rev. 2000, 206, 263-283.

[2] a) B. Liu, T. Roisnel, L. Maron, J.-F. Carpentier, Y. Sarazin, Chem. Eur. J. 2013, 19, 3986-3994; b) I. V. Basalov, V. Dorcet, G. K. Fukin, J.-F. Carpentier, Y. Sarazin, A. A. Trifonov, Chem. Eur. J. 2015, 21, 60336036; c) M. Szostak, N. J. Fazakerley, D. Parmar, D. J. Procter, Chem. Rev. 2014, 114, 5959-6039.

[3] a) M. Nishiura, Z. Hou, Nat. Chem. 2010, 2, 257-268; b) D. J. Berg, J. M. Boncella, R. A. Andersen, Organometallics 2002, 21, 4622-4631; c) G. Nocton, W. W. Lukens, C. H. Booth, S. S. Rozenel, S. A. Medling, L. Maron, R. A. Andersen, J. Am. Chem. Soc. 2014, 136, 8626-8641.

[4] a) J. M. Veauthier, E. J. Schelter, C. N. Carlson, B. L. Scott, R. E. Da Re, J. D. Thompson, J. L. Kiplinger, D. E. Morris, K. D. John, Inorg. Chem. 2008, 47, 5841-5849; b) W. J. Evans, J. Alloys Compd. 2009, 
488, 493-510; c) G. Meyer, Angew. Chem. Int. Ed. Engl. 2008, 47, 4962-4964.

[5] a) W. J. Evans, J. M. Perotti, J. C. Brady, J. W. Ziller, J. Am. Chem. Soc 2003, 125, 5204-5212; b) W. J. Evans, C. A. Seibel, J. W. Ziller, Inorg Chem. 1998, 37, 770-776; c) J. Andrez, J. Pecaut, P.-A. Bayle, M Mazzanti, Angew. Chem. Int. Ed. 2014, 53, 10448-10452; d) N. W. Davies, A. S. P. Frey, M. G. Gardiner, J. Wang, Chem. Commun. 2006 4853-4855.

[6] a) G. B. Deacon, P. C. Junk, J. Wang, D. Werner, Inorg. Chem. 2014 53, 12553-12563; b) D. Heitmann, C. Jones, D. P. Mills, A Stasch,.Dalton Trans. 2010, 39, 1877-1882; c) L. Castro, S. Labouille D. R. Kindra, J. W. Ziller, F. Nief, W. J. Evans, L. Maron, Chem. Eur. J. 2012, 18, 7886-7895.

[7] a) W. J. Evans, D. S. Lee, Can. J. Chem. 2005, 83, 375-384; b) M. G. Gardiner, D. N. Stringer, Materials 2010, 3, 841-862; c) T. Dube, S Conoci, S. Gambarotta, G. P. A. Yap, G. Vasapollo, Angew. Chem. Int. Ed 1999, 38, 3657-3659.

[8] M. E. Fieser, M. R. MacDonald, B. T. Krull, J. E. Bates, J. W. Ziller, F. Furche, W. J. Evans, J. Am. Chem. Soc. 2015, 137, 369-382.

[9] a) M. L. Cole, P. C. Junk, Chem. Commun. 2005, 2695-2697; b) M. L. Cole, G. B. Deacon, C. M. Forsyth, P. C. Junk, K. Konstas, J. Wang, H Bittig, D. Werner, Chem. Eur. J. 2013, 19, 1410-1420; c) R. Kempe, Angew. Chem. Int. Ed 2000, 39, 468-493; d) P. W. Roesky, Chem. Soc Rev. 2000, 29, 335-345; e) F. T. Edelmann, D. M. M. Freckmann, H. Schumann, Chem. Rev. 2002, 102, 1851-1896; f) W. E. Piers, D. J. H. Emslie, Coord. Chem. Rev. 2002, 233, 131-155; g) G. B. Deacon, C. M. Forsyth, P. C. Junk, B. W. Skelton, A. H. White, Chem. Eur. J. 1999, 5, 1452-1459; h) Z. M. Hou, T. Miyano, H. Yamazaki, Y. Wakatsuki, J. Am. Chem. Soc. 1995, 117, 4421-4422; i) W. J. Evans, D. S. Lee, J. W. Ziller, J. Am. Chem. Soc. 2004, 126, 454-455.

[10] a) J. Jenter, M. T. Gamer, P. W. Roesky, Organometallics 2010, 29 4410-4413; b) I. V. Basalov, S. C. Rosca, D. M. Lyubov, A. N. Selikhov G. K. Fukin, Y. Sarazin, J.-F. Carpentier, A. A. Trifonov, Inorg. Chem 2014, 53, 1654-1661.

[11] G. Anderegg, E. Hubmann, N. G. Podder, F. Wenk, Helv. Chim. Acta 1977, 60, 123-140.

[12] O. Wichmann, R. Sillanpaa, A. Lehtonen, Coord. Chem. Rev. 2012 256, 371-392

[13] a) L. Karmazin, M. Mazzanti, J. Pecaut, Inorg. Chem. 2003, 42, 5900 5908; b) W. A. Chomitz, S. G. Minasian, A. D. Sutton, J. Arnold, Inorg Chem. 2007, 46, 7199-7209; c) R. Wietzke, M. Mazzanti, J.-M. Latour, J. Pécaut, J. Chem. Soc. Dalton Trans. 1998, 4087-4088; d) R. Wietzke M. Mazzanti, J.-M. Latour, J. Pecaut, P.-Y. Cordier, C. Madic, Inorg. Chem. 1998, 37, 6690-6697; e) T. Andrea, E. Barnea, M. Botoshansky, M. Kapon, E. Genizi, Z. Goldschmidt, M. S. Eisen, J. Organomet. Chem 2007, 692, 1074-1080.

[14] Y. Takashi, S. Shinoda, H. Sugimoto, J.-i. Uenishi, H. Tsukube, Inorg. Chem. 2003, 42, 7932-7937.

[15] a) L. Natrajan, J. Pécaut, M. Mazzanti, C. LeBrun, Inorg. Chem. 2005 44, 4756-4765; b) P. Benndorf, S. Schmitt, R. Koeppe, P. Ona-Burgos A. Scheurer, K. Meyer, P. W. Roesky, Angew. Chem. Int. Ed. 2012, 51, 5006-5010.

[16] D. T. Dugah, B. W. Skelton, E. E. Delbridge, Dalton Trans. 2009, 14361445 .
[17] a) A. Amgoune, C. M. Thomas, T. Roisnel, J. F. Carpentier, Chem. Eur. J. 2006, 12, 169-179; b) F. Bonnet, A. R. Cowley, P. Mountford, Inorg. Chem. 2005, 44, 9046-9055; c) H. E. Dyer, S. Huijser, N. Susperregui, F. Bonnet, A. D. Schwarz, R. Duchateau, L. Maron, P. Mountford, Organometallics 2010, 29, 3602-3621; d) M. A. Sinenkov, G. K. Fukin, A. V. Cherkasov, N. Ajellal, T. Roisnel, F. M. Kerton, J.-F. Carpentier, A. A. Trifonov, New J. Chem. 2011, 35, 204-212; e) Z. Du, Y. Zhang, Y. Yao, Q. Shen, Dalton Trans. 2011, 40, 7639-7644; f) C. E. Willans, M. A. Sinenkov, G. K. Fukin, K. Sheridan, J. M. Lynam, A. A. Trifonov, F. M. Kerton, Dalton Trans. 2008, 3592-3598; g) K. Nie, X. Gu, Y. Yao, Y. Zhang, Q. Shen, Dalton Trans. 2010, 39, 6832-6840; h) Y. M. Yao, M. T. Ma, X. P. Xu, Y. Zhang, Q. Shen, W. T. Wong, Organometallics 2005, 24, 4014-4020; i) C. X. Cai, A. Amgoune, C. W. Lehmann, J. F. Carpentier, Chem. Commun. 2004, 330-331; j) Z. M. Hou, Y. Wakatsuki, Coord. Chem. Rev. 2002, 231, 1-22.

[18] a) H. Zhou, H. Guo, Y. Yao, L. Zhou, H. Sun, H. Sheng, Y. Zhang, Q. Shen, Inorg. Chem. 2007, 46, 958-964; b) H. Guo, H. Zhou, Y. Yao, Y. Zhang, Q. Shen, Dalton Trans. 2007, 3555-3561; c) E. E. Delbridge, D. T. Dugah, C. R. Nelson, B. W. Skelton, A. H. White, Dalton Trans. 2007, 143-153.

[19] a) S. Yang, Z. Du, Y. Zhang, Q. Shen, Chem. Commun. 2012, 48, 9780-9782; b) M. Zhang, X. Ni, Z. Shen, Organometallics 2014, 33 , 6861-6867.

[20] S. C. Marinescu, T. Agapie, M. W. Day, J. E. Bercaw, Organometallics 2007, 26, 1178-1190.

[21] T. Toupance, S. R. Dubberley, N. H. Rees, B. R. Tyrrell, P. Mountford, Organometallics 2002, 21, 1367-1382.

[22] R. D. Shannon, Acta Crystallogr A 1976, 32, 751-767.

[23] a) W. J. Evans, M. A. Greci, J. W. Ziller, Chem. Commun. 1998, $2367-$ 2368; b) T. J. Boyle, L. A. M. Ottley, Chem. Rev. 2008, 108, 1896-1917.

[24] a) P. Caravan, T. Hedlund, S. Liu, S. Sjoberg, C. Orvig, J. Am. Chem. Soc. 1995, 117, 11230-11238; b) R. Wietzke, M. Mazzanti, J. M. Latour, J. Pecaut, Chem. Commun. 1999, 209-210.

[25] R. S. Selinsky, J. H. Han, E. A. M. Perez, I. A. Guzei, S. Jin, J. Am. Chem. Soc. 2010, 132, 15997-16005.

[26] C. Camp, O. Cooper, J. Andrez, J. Pecaut, M. Mazzanti, J. Chem. Soc.Dalton Trans. 2015, 44, 2650-2656.

[27] O. P. Lam, L. Castro, B. Kosog, F. W. Heinemann, L. Maron, K. Meyer, Inorg. Chem. 2012, 51, 781-783.

[28] Y. L. Tong, Y. Yan, E. S. H. Chan, Q. C. Yang, T. C. W. Mak, D. K. P. Ng, J. Chem. Soc.-Dalton Trans. 1998, 3057-3064.

[29] S. Zheng, T. C. Berto, E. W. Dahl, M. B. Hoffman, A. L. Speelman, N. Lehnert, J. Am. Chem. Soc. 2013, 135, 4902-4905.

[30] A. Thapper, A. Behrens, J. Fryxelius, M. H. Johansson, F. Prestopino, M. Czaun, D. Rehder, E. Nordlander, Dalton Trans. 2005, 3566-3571.

[31] CrysAlisPro CCD; CrysAlisPro RED ; ABSPACK; CrysAlis PRO. Agilent Technologies: Yarnton, England., Agilent (2010).

[32] L. Palatinus, G. Chapuis, J. Appl. Crystallogr. 2007, 40, 786-790.

[33] A. J. M. Duisenberg, L. M. J. Kroon-Batenburg, A. M. M. Schreurs, J. Appl. Crystallogr. 2003, 36, 220-229.

[34] R. H. Blessing, Acta Crystallogr., Sect. A 1995, 51, 33-38.

[35] SHELX, G. M. Sheldrick, Acta Crystallogr., Sect. A 2008, 64, 112-122.

[36] PLATON, A.L.Spek, Acta Crystallogr., Sect. D 2009, 65, 148-155 


\section{Entry for the Table of Contents}

\section{FULL PAPER}

Tuning reducing power.

The successive replacement of pyridyl groups with phenolate groups in tripodal ligands results in a higher reducing power of the respective $\mathrm{Ln}(\mathrm{II})$ homoleptic complexes. The [Eu(BPA)2] complex reduces $\mathrm{CS}_{2}$ affording the first example of a lanthanide trithiocarbonate.

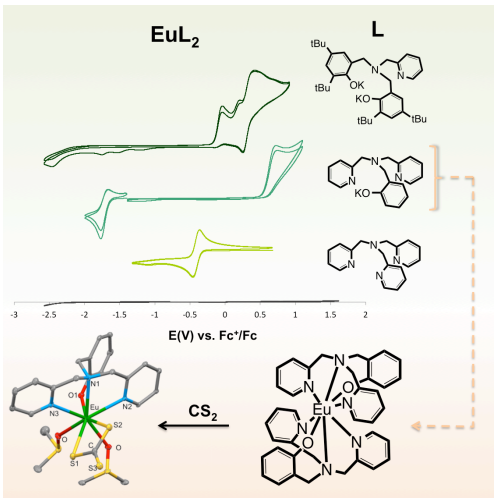

Julie Andrez, Gülay Bozoklu, Grégory Nocton, Jacques Pécaut, Rosario Scopelliti, Lionel Dubois and Marinella Mazzanti*

\section{Page No. - Page No.}

Lanthanide(II) Complexes Supported by N,O-Donor Tripodal Ligands: Synthesis, Structure and LigandDependent Redox Behavior 